\title{
SHRIMP U-Pb zircon dating of anatexis in high-grade migmatite complexes of Central Spain: implications in the Hercynian evolution of Central Iberia
}

\author{
Pedro Castiñeiras • Carlos Villaseca • \\ Luis Barbero • Cristina Martín Romera
}

\begin{abstract}
U-Pb SHRIMP ages obtained in zircons from the Sotosalbos and Toledo anatectic complexes in Central Spain give new constraints to the evolution of the inner part of the Hercynian Iberian belt. PreHercynian ages in zircons from the Sotosalbos complex $(-464 \mathrm{Ma})$ are well preserved and reveal that an age diversity of the Lower Paleozoic magmatism in the area exists, as previous data on westernmost orthogneisses yield significant older ages. Zircon ages in the pelite-derived granites from the Toledo complex also show an important Neoproterozoic age component which points to a metasedimentary protolith deposited maximally $560 \mathrm{Ma}$ ago. Younger zircon populations in both complexes at $-330 \mathrm{Ma}$ in the Sotosalbos region and $-317 \mathrm{Ma}$ in the Toledo complex indicate an important diachronism between the anatectic processes in both areas but also that these processes are mainly unrelated to the generation of the later Hercynian granite batholith of Central Spain, which could be of deeper crustal derivation. In
\end{abstract}

addition, as migmatization occurred late in the metamorphic cycle, after peak conditions were attained, the age of anatexis is younger than the age of the main Hercynian metamorphic event, which still is not well constrained.

Keywords SHRIMP U-Pb zircon dating - Migmatite complexes - Anatectic granites - Hercynian Iberian Belt - Gondwana zircon provenance

\section{Introduction}

A typical continental collision orogenic cycle is usually composed of a stage of convergence and crustal thickening followed by a period of crustal thinning. The study of migmatite complexes provides evidence to decipher the history of late metamorphic and magmatic processes during orogeny, and precise dating of migmatization is essential to model the waning stages of orogenesis. In this way, topics like the relation of the migmatites to the temperature peak or their late origin in exhumed-uplifted sectors and their age-relationships with the late, discordant plutonic bodies are important questions that need geochronological data to be addressed. In addition, the refractory character of zircon allows us to study the age and nature of their protoliths. In this work, we present the $\mathrm{U}-\mathrm{Pb}$ age results from five samples collected in two well known anatectic complexes in Central Spain (Fig. 1): the anatectic complex of Sotosalbos (ACS) in the Spanish central system (SCS) and the anatectic complex of Toledo (ACT) (Barbero 1995; Barbero et al. 1995; Martín Romera et al. 1999; Villaseca et al. 2001). 
Fig. 1 Simplified geological sketch of the Central Iberian Zone (Iberian Massif, inset) in Central Spain. The anatectic areas described in the text are boxed

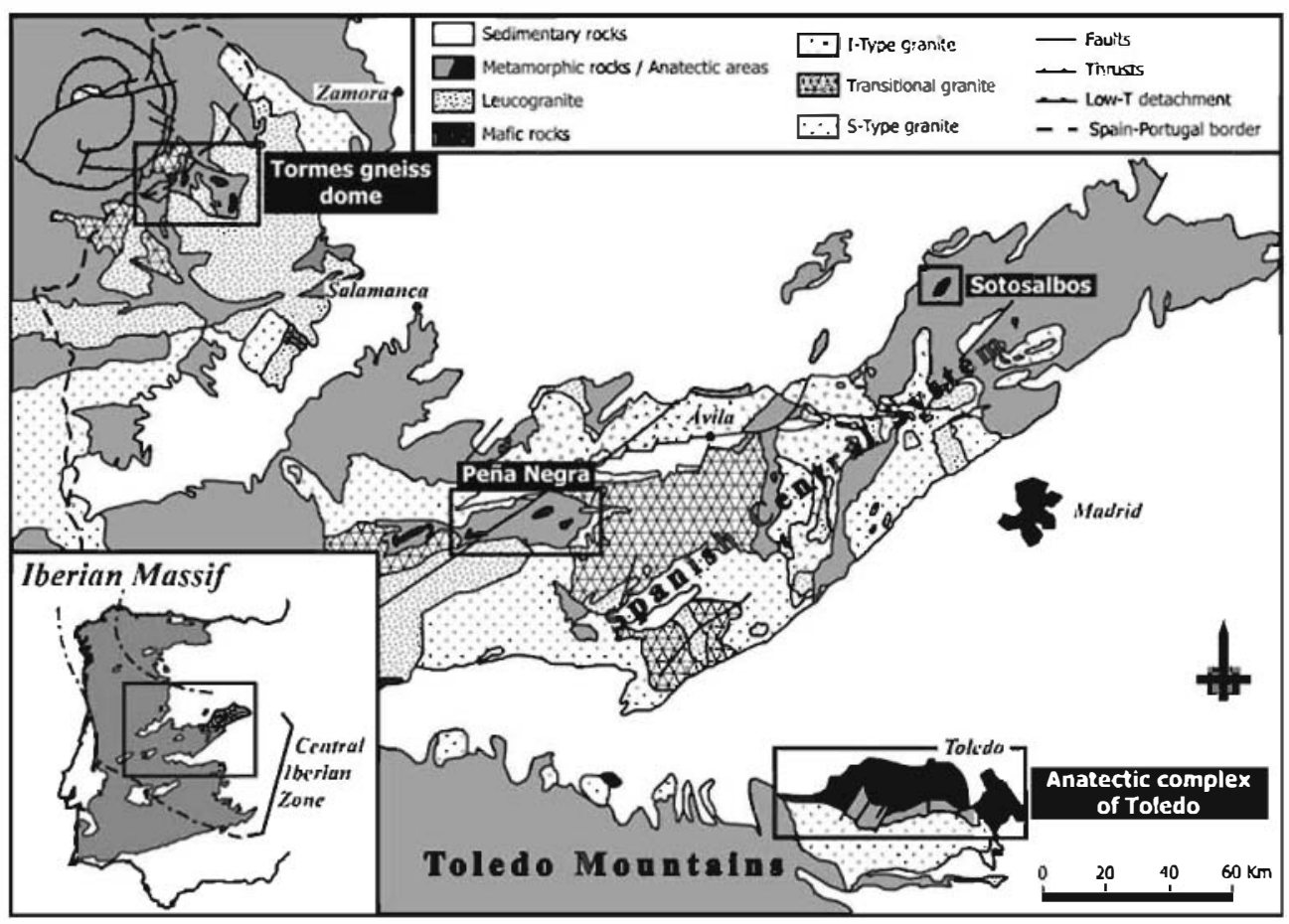

\section{Geological setting and petrographic features of migmatites}

The ACS and ACT complexes crop out in the Central Iberian Zone of the Iberian Massif (Julivert et al. 1972), one of the best preserved sections of the European Hercynian Belt. It is generally accepted that the Central Iberian Zone represents a piece of the external margin of northern Gondwana, involved in the Paleozoic collision with Laurentia after the closure of the Rheic Ocean (see Gibbons and Moreno 2002, and references therein), and it is mainly composed of plutonic and variably metamorphosed rocks, including several migmatite complexes (Fig. 1). In these migmatite areas, peak metamorphic conditions were attained during or immediately after the first Hercynian tectonothermal stage $\left(\mathrm{M}_{1}\right)$, reaching eclogite or granulite facies depending on the structural level (Villaseca et al. 1999), followed by an exhumation stage with pressure differences of around $9-10 \mathrm{~kb}$ from peak pressure conditions of $-14 \mathrm{~kb}$ and re-equilibration pressures of $4-5 \mathrm{~kb}$ (Escuder Viruete et al. 1998; Barbero and Villaseca 2000). Available petrological data indicate that the SCS and nearby areas have recorded a clockwise $P-T$-time $(t)$ evolution and that migmatization is related, to a certain extent, to the low$P$ loop, when temperature was decreasing (Villaseca et al. 2002; Villaseca and Ubanell 2005).

In the ACS, located in the eastern part of the SCS (Fig. 1), the migmatites and the related anatectic granites have cordierite and biotite as mafic minerals, and migmatite metamorphic conditions are estimated around $725 \pm 50^{\circ} \mathrm{C}$ and $4-5 \mathrm{~kb}$ (Martín Romera et al. 1999). The nearby Peña Negra anatectic complex in the western SCS (Fig. 1), shows similar metamorphic characteristics (Bea et al. 1994; Pereira and Rodríguez Alonso 2000). In contrast, the ACT migmatites, located north to the Toledo Mountains (Fig. 1), are characterized by garnet and cordierite as mafic minerals and their calculated metamorphic conditions are $800 \pm 25^{\circ} \mathrm{C}$ and $4-6 \mathrm{~kb}$ (Barbero 1995).

In the ACS, the petrographic and geochemical features of the cordierite-bearing granitoids indicate that they represent restite-rich granites related to migmatized orthogneisses. These anatectic granitoids locally contain cordierite-rich nodules and cockades, corroded augen $\mathrm{K}$-feldspar megacrysts, and orthogneissic xenoliths, suggestive of their derivation from those metaigneous protoliths. Moreover, trace and major element geochemistry combined with $\mathrm{Sr}-\mathrm{Nd}$ isotopes show a good agreement with this orthogneissic derivation (Martín Romera et al. 1999). Two samples from this heterogeneous Sotosalbos cordierite granite were selected (100560 and 100943). They are mediumgrained equigranular rocks consisting of quartz, plagioclase, K-feldspar, biotite, cordierite and accessory tourmaline. Cordierite contains minor inclusions of biotite and sillimanite. Feldspar also contains needles of sillimanite. Some scarce biotite-rich enclaves resemble biotite-rich folia of the augen-gneisses. 
Migmatites of the ACT are mostly derived from pelitic metasediments. Related anatectic leucogranites (Cervatos-type) and restite-rich granitoids (Layostype) appear in the ACT (Barbero et al. 1995). The Layos granite constitutes a suite of rocks ranging from quartz-rich tonalite to melamonzogranite and is characterized by a high modal proportion of cordierite (up to $30 \%$ ). This restite-rich granite is more peraluminous in the more mafic types, a remarkable characteristic of some S-type granites in which more mafic rocks (Qtzrich tonalites) are closer to the composition of their source rocks (Chappell and White 1992; Barbero and Villaseca 1992). The Cervatos leucogranite crops out as vein-like or dyke-like concordant sheets or elongated massifs and, in most cases, is spatially related to the Layos granite. This leucogranite has a modal eutectic composition and displays centimetre-scale layering consisting of garnet-, cordierite- and less frequent biotite-bearing varieties. Two samples of the restiterich Layos granite (M-3 and LY-1) and the Cervatos leucogranite ( $\mathrm{CV}-1)$ have been selected for zircon analysis in this work.

\section{Previous geochronology}

Reliable geochronological information available on the Hercynian migmatization in the Central Iberian Zone is scarce, and the knowledge of its relationship with either the pressure peak or the granite intrusions which built the huge SCS Batholith is limited. Montero et al. (2004) studied a migmatite area outcropping in the western part of the SCS, the Peña Negra Complex (Fig. 1), and they presented a discussion on the implications of the geochronology of migmatite complexes in the Hercynian evolution of the sector. In this work, the authors stated that anatexis occurred for a long period, from 352 to $297 \mathrm{Ma}$, with a maximum at 335-305 Ma, suggesting a coeval emplacement of massif-type granites in mid-crustal levels. Nevertheless, a U-Pb SHRIMP zircon geochronology study in orthogneisses from this Peña Negra Complex suggests an age of $315 \mathrm{Ma}$ for the climax of the Hercynian metamorphism in the western SCS (Zeck et al. 2004). At the starting point of this study, the geochronological data in the Toledo area was limited to a short communication on the anatectic granites from the southern ACT (Barbero and Rogers 1999), giving an age of $310 \mathrm{Ma}$ (U-Pb ID-TIMS in monazites) for the anatectic event. However, recently Bea et al. (2006) have published a SIMS U-Pb zircon study on the temporal relationships between the mafic magmatism and the migmatization in the Toledo area in which they obtained a mean migmatization age of 332 Ma.

In addition, some studies have been devoted to the geochronology of the Hercynian $\mathrm{M}_{2}$ metamorphism in the SCS. U-Pb dating in monazites indicates that the main $\mathrm{D}_{2}$ extensional event (related to the temperature peak) in the eastern part of the SCS took place between 337 and 326 Ma (Escuder Viruete et al. 1998), in accordance with the only $\mathrm{U}-\mathrm{Pb}$ geochronological study on zircons from the western SCS (332 Ma, after Galibert 1984).

Other relevant ages are mainly related to the preHercynian evolution of the Central Iberian Zone. Vialette et al. (1987) presented whole-rock Rb-Sr isochrons from three granitic orthogneisses in the Guadarrama area at around 475-490 Ma, which was interpreted as the intrusion ages of the respective granite magmas. Wildberg et al. (1989) dated six orthoand para-gneisses east from Sotosalbos (U-Pb IDTIMS in zircon), yielding Paleoproterozoic upper intercepts, which were interpreted as inherited ages and $-550 \mathrm{Ma}$ lower intercepts, considered as magmatic ages. In addition, they obtained two younger ages related to the Hercynian evolution, -380 and 280$300 \mathrm{Ma}$. Lancelot et al. (1985) dated orthogneisses from the northwestern sector of the Central Iberian Zone, obtaining discordant ages with an upper intercept at $465 \mathrm{Ma}$ (U-Pb ID-TIMS in zircon), and interpreted as a magmatic age. Valverde-Vaquero and Dunning (2000) obtained similar ages (-460-490 Ma, $\mathrm{U}-\mathrm{Pb}$ ID-TIMS in zircon) in orthogneisses located in the Guadarrama area, east of Sotosalbos. More recently, Zeck et al. (2004) dated zircons from another orthogneissic unit southwest of the Peña Negra Complex using SHRIMP, and their results exhibited evidence of the complex history recorded in these rocks in which inherited zircons show different populations between 1,000 and $570 \mathrm{Ma}$ that were incorporated to a magma at $546 \mathrm{Ma}$ and subsequently metamorphosed at -315 Ma.

\section{Zircon description}

Zircons from sample 100560 (a cordierite-bearing granite from ACS) are usually slightly worn out prisms (aspect ratios between 1:2 and 1:3) with distinguishable rims even under a transmitted light microscope. Some longer (1:4-1:7), well-formed prisms can also be found which show no apparent core-rim features under the microscope. Cathodoluminescence images (CL) reveal xenocrystic, inherited cores with variable CL response (Fig. 2). These cores can be surrounded by a light 

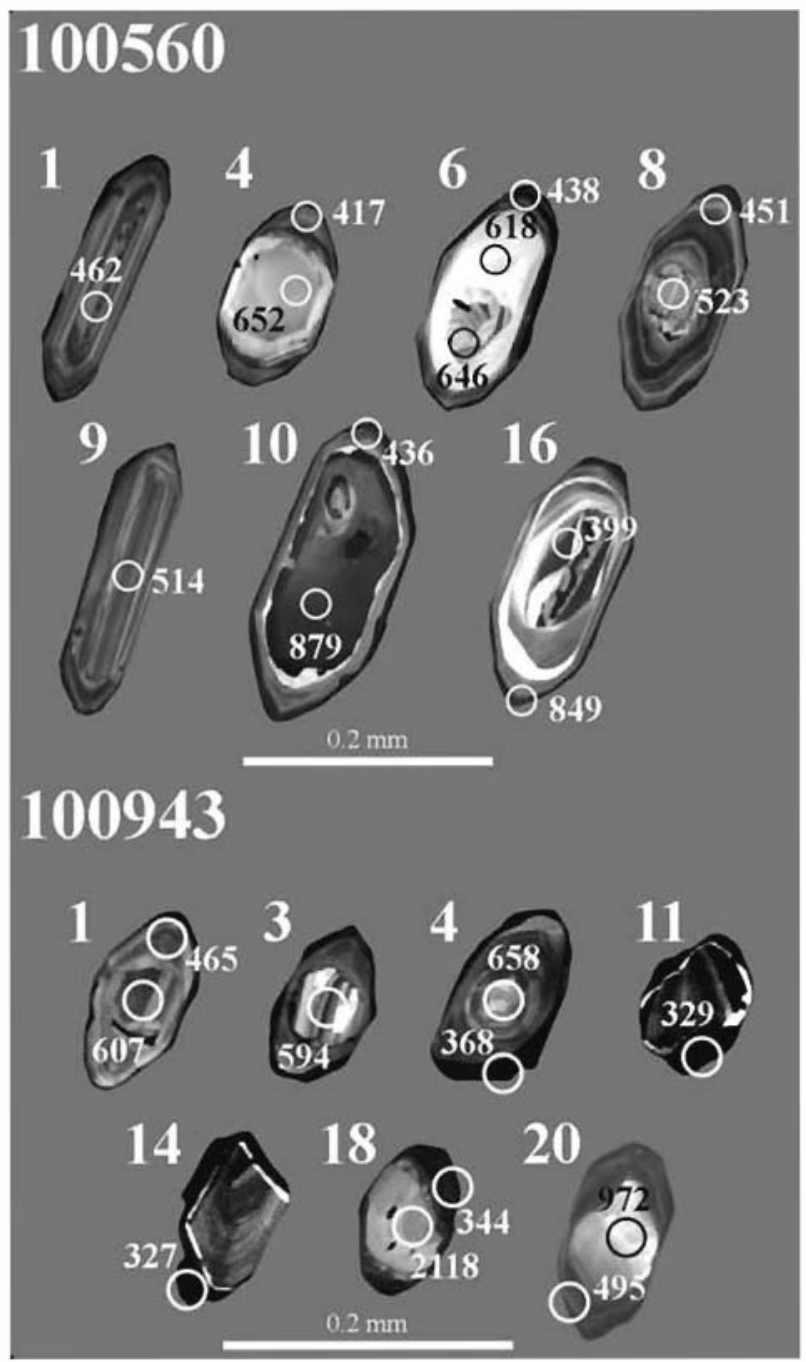

Fig. 2 Cathodoluminescence images of the analyzed zircons from Sotosalbos (samples 100560 and 100943), with the location of the SHRIMP spots

mantle or by a variably thick overgrowth with oscillatory zoning (Fig. 2). The longest prisms exhibit magmatic oscillatory zoning but no cores. Finally, irregular, dark rims $(-15 \mu \mathrm{m}$ thick $)$ can be found in some grains, irrespective of the type of zircon.

Sample 100943 corresponds to the same lithology as the previous sample, and zircons display the same corerim features although they are usually smaller and stubbier. Under CL (Fig. 2), a varied population of xenocrysts can be observed; mantles and oscillatory overgrowths are scarce, but irregular dark rims are common ( $-15 \mu \mathrm{m}$ thick).

Zircons from sample $\mathrm{CV}-1$, an anatectic leucogranite from the ACT, are highly variable, showing differences in size and shape from stubby grains to rounded prisms (1:3-1:5). Core-rim associations are evident, and sometimes a marked oscillatory zoning can be observed even under a transmitted light microscope. CL enhances these core-rim features, showing cores with different luminescence responses always truncated by $-20 \mu \mathrm{m}$ thick dark rims (Fig. 3). In some cases, dark CL areas do not form rims but occupy irregular domains, giving rise to an embayed morphology in the former zircons.

In samples LY-1 and M-3, which are restite-rich granitoids from the ACT, zircons are quite similar. As in $\mathrm{CV}-1$, they are variable in size and shape although small, stubby grains with distinguishable cores and rims under the microscope are dominant. CL images (Fig. 3) reveal that most of the zircons have oscillatoryzoned cores, truncated by dark CL zircon, mainly in the tips. In other cases, there is no overgrowth or it thinly surrounds the whole zircon and has oscillatory zoning as well.

\section{Analytical techniques}

Zircons were isolated following standard separation techniques, followed by hand picking for final purity, and mounted on a double stick tape on glass slides in $1 \times 6 \mathrm{~mm}$ parallel rows together with some chips of zircon standard R33 (Black et al. 2004). After setting them in epoxy resin, the zircons were ground down to expose their central portions and imaged with transmitted and reflected light on a petrographic microscope as well as with cathodoluminescence on a JEOL 5800LV electron microscope (housed at USGS-Denver) to identify internal structures, inclusions, fractures and physical defects. Due to the textural complexity of the zircons, the use of CL images was central to aim at the right area.

Zircon U-Th- $\mathrm{Pb}$ analyses were conducted on the sensitive high resolution ion microprobe-reverse geometry (SHRIMP-RG) operated by the SUMAC facility (USGS-Stanford University). Secondary ions were generated from the target spot with an $\mathrm{O}^{2-}$ primary ion beam varying from 4-6 n A which typically produced a spot with a diameter of $\sim 20$ microns and a depth of 1-2 microns for an analysis time of approximately $10 \mathrm{~min}$. When analyzing rims slightly thinner than the ion beam diameter, the spot was preferably located at the very edge of the zircon, touching the epoxy resin, to avoid core-rim mixed ages. Twelve peaks were measured sequentially in a single collector. Measurements were made at mass resolution of 6,000 8,000 ( $10 \%$ peak height) which eliminated all interfering atomic species. The reverse geometry of the USGS-Stanford SHRIMP provided very clean backgrounds, and combined with the high mass resolution, 
Fig. 3 Cathodoluminescence images of the analyzed zircons from Toledo (samples CV-1, LY-1 and M-3) with the location of the SHRIMP spots
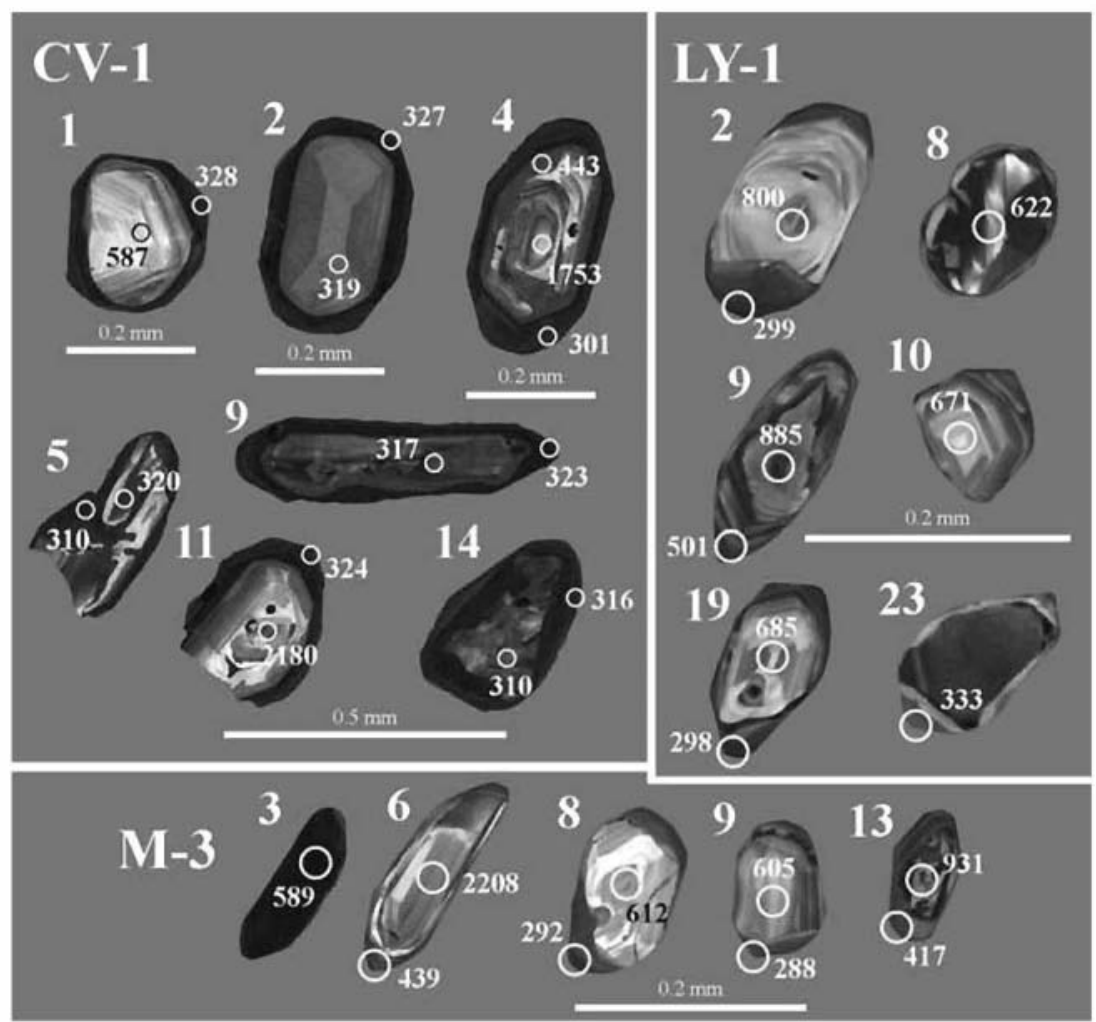

the acid washing of the mount and rastering the primary beam for $90-120$ s over the area to be analyzed before data was collected, assured that any counts found at mass ${ }^{204} \mathrm{~Pb}$ were actually from the zircon.

The accuracy using ion microprobe techniques is achieved at the expense of the precision of the results, as a very small volume of material is sampled. Nevertheless, the precision can be statistically improved by pooling a set of equivalent data together. For this reason, the significance of single results, such as those obtained in detrital populations, can be difficult to evaluate as the occurrence of lead loss can remain unrecognized.

In addition, zircons younger than 1,000 Ma yield poor ${ }^{207} \mathrm{~Pb} /{ }^{206} \mathrm{~Pb}$ ages, thus reducing the efficacy of the $\mathrm{U}-\mathrm{Pb}$ dating method. In order to minimize this drawback, the counting time for ${ }^{206} \mathrm{~Pb}$ was increased to improve counting statistics and precision of the ${ }^{206} \mathrm{~Pb} /{ }^{238} \mathrm{U}$ age.

Concentration data were normalized against zircon standard CZ3 (550 ppm U, Pidgeon et al. 1995), and isotope ratios were calibrated against R33 (419 Ma, Black et al. 2004) which were analyzed repeatedly throughout the duration of the analytical session. Data reduction followed the methods described by Williams (1997), Ireland and Williams (2003), and Squid 1.08 and Isoplot 3.0 software (Ludwig 2002, 2003) were used.

\section{Results}

One hundred-sixteen zircon grains were analyzed in the five samples selected. In almost half of them two or three spots were performed, resulting in a total of 168 analyses. Despite all the measures taken in selecting the adequate spots to prevent common lead contamination, twenty-two of the $<1,000 \mathrm{Ma}$ analyses had common ${ }^{206} \mathrm{~Pb}$ greater than $1 \%$, and they will not be considered in the further discussions. A representative set of analytical data is listed in Tables 1,2 and 3 and plotted in Tera-Wasserburg concordia diagrams (Figs. 4, 5) and probability density diagrams (Figs. 6, 7). The complete set of U-Pb SHRIMP data is provided as supplementary material. Ages younger than $1,000 \mathrm{Ma}$ are 207 -corrected ${ }^{206} \mathrm{~Pb} /{ }^{238} \mathrm{U}$, whereas older ages are 204-corrected ${ }^{207} \mathrm{~Pb} /{ }^{206} \mathrm{~Pb}$.

\section{Anatectic complex of Sotosalbos (ACS)}

On the bases of CL images and $\mathrm{U}-\mathrm{Pb}$ data results, four groups of ages can be distinguished in sample 100560 (Fig. 6). A predominant mean age of $464 \pm 2.6 \mathrm{Ma}$ (MSWD $=0.47$ ) is obtained from five magmatic oscillatory zones (Figs. 4, 6). Older ages are mainly early Paleozoic and Neoproterozoic (500-585 Ma, 620$650 \mathrm{Ma}$ and 780-880 Ma), and a single analysis yields $-1,260 \mathrm{Ma}$. Pre-Hercynian ages younger than $464 \mathrm{Ma}$ 
Table 1 U-Th-Pb SHRIMP representative analytical data for young zircons from the Anatectic Complex of Sotosalbos

\begin{tabular}{|c|c|c|c|c|c|c|c|c|c|c|c|}
\hline \multicolumn{2}{|c|}{$\begin{array}{l}\text { Spot number } \\
\text { and descriplicis }\end{array}$} & $\begin{array}{l}\text { Common } \\
{ }^{206} \mathrm{~Pb}\left({ }^{0 / 6}\right)\end{array}$ & $\mathrm{U}$ (реті) & Th (ppm) & $\mathrm{Th} / \mathbf{U}$ & ${ }^{238} \mathrm{U}^{206} \mathrm{~Pb}^{\mathrm{a}}$ & ${ }^{207} \mathrm{~Pb} /{ }^{206} \mathrm{~Pb}^{\mathrm{a}}$ & ${ }^{238} \mathrm{U} /{ }^{206} \mathrm{~Pb}^{\mathrm{b}}$ & ${ }^{207} \mathrm{~Pb} /{ }^{206} \mathrm{~Pb}^{\mathrm{b}}$ & ${ }^{206} \mathrm{~Pb} /{ }^{238} \mathrm{U}^{\mathrm{c}}$ & ${ }^{206} \mathrm{~Pb} /{ }^{238} \mathrm{U}^{\mathrm{d}}$ age \\
\hline \multicolumn{12}{|c|}{ Anatectic complex of Sotosalbos } \\
\hline \multicolumn{12}{|c|}{ Sample 100560} \\
\hline 1 & $\mathrm{C}$ & $<0.001$ & 314 & 39 & 0.12 & $13.46583 \pm 0.69$ & $0.05553 \pm 1.93$ & $13.49028 \pm 0.69$ & $0.05405 \pm 2.09$ & $0.0743 \pm 0.0005$ & $462 \pm 3$ \\
\hline 4.1 & $\mathrm{C}$ & $<0.001$ & 101 & 165 & 1.63 & $9.41450 \pm 1.20$ & $0.05985 \pm 2.87$ & $9.47005 \pm 1.22$ & $0.05501 \pm 4.29$ & $0.1064 \pm 0.0013$ & $652 \pm 8$ \\
\hline 4.2 & $\mathrm{R}$ & 0.238 & 574 & 26 & 0.04 & $14.92854 \pm 0.41$ & $0.05704 \pm 1.18$ & $14.95125 \pm 0.42$ & $0.05582 \pm 1.77$ & $0.0668 \pm 0.0003$ & $417 \pm 2$ \\
\hline 6.1 & $\mathrm{C}$ & 0.031 & 113 & 37 & 0.33 & $9.48326 \pm 0.98$ & $0.06144 \pm 2.33$ & $9.50469 \pm 0.98$ & $0.05959 \pm 2.81$ & $0.1054 \pm 0.0011$ & $646 \pm 6$ \\
\hline 6.2 & LA & 0.232 & 46 & 12 & 0.27 & $9.91221 \pm 1.53$ & $0.06231 \pm 3.64$ & $9.96183 \pm 1.55$ & $0.05822 \pm 4.88$ & $0.1007 \pm 0.0016$ & $618 \pm 9$ \\
\hline 6.3 & $\mathrm{R}$ & 7.466 & 635 & 12 & 0.02 & $13.16232 \pm 0.36$ & $0.11609 \pm 3.75$ & $14.14043 \pm 0.80$ & $0.06042 \pm 17.36$ & $0.0703 \pm 0.0009$ & $438 \pm 5$ \\
\hline 8.1 & $\mathrm{C}$ & 11.011 & 234 & 39 & 0.17 & $10.52811 \pm 0.76$ & $0.14741 \pm 2.14$ & $11.84773 \pm 1.26$ & $0.05666 \pm 27.19$ & $0.0845 \pm 0.0015$ & $523 \pm 9$ \\
\hline 8.2 & $\mathrm{R}$ & 0.045 & 359 & 38 & 0.11 & $13.78516 \pm 0.56$ & $0.05634 \pm 1.57$ & $13.79583 \pm 0.56$ & $0.05571 \pm 1.76$ & $0.0725 \pm 0.0004$ & $451 \pm 3$ \\
\hline 9 & $\mathrm{R}$ & 0.159 & 302 & 147 & 0.49 & $12.03233 \pm 0.55$ & $0.05887 \pm 1.44$ & $12.05733 \pm 0.55$ & $0.05719 \pm 1.59$ & $0.0830 \pm 0.0005$ & $514 \pm 3$ \\
\hline 10.1 & $\mathrm{C}$ & 0.190 & 588 & 110 & 0.19 & $6.83285 \pm 0.44$ & $0.06992 \pm 0.86$ & $6.83550 \pm 0.44$ & $0.06959 \pm 0.86$ & $0.1461 \pm 0.0007$ & $879 \pm 4$ \\
\hline 10.2 & $\mathrm{R}$ & $<0.001$ & 600 & 5 & 0.01 & $14.30002 \pm 0.49$ & $0.05488 \pm 1.49$ & $14.30973 \pm 0.50$ & $0.05433 \pm 1.72$ & $0.0700 \pm 0.0004$ & $436 \pm 2$ \\
\hline 16.1 & $\mathrm{C}$ & 0.335 & 534 & 90 & 0.17 & $7.07594 \pm 0.63$ & $0.07016 \pm 1.04$ & $7.08270 \pm 0.64$ & $0.06937 \pm 1.25$ & $0.1409 \pm 0.0009$ & $849 \pm 5$ \\
\hline 16.2 & $\mathrm{R}$ & 5.909 & 1945 & 171 & 0.09 & $14.73655 \pm 0.44$ & $0.10241 \pm 1.05$ & $15.67710 \pm 0.63$ & $0.05389 \pm 13.85$ & $0.0638 \pm 0.0006$ & $399 \pm 4$ \\
\hline \multicolumn{12}{|c|}{ Sample 100943} \\
\hline 1.1 & $\mathrm{C}$ & 0.021 & 301 & 282 & 0.94 & $10.13100 \pm 0.58$ & $0.06026 \pm 1.41$ & $10.13917 \pm 0.58$ & $0.05960 \pm 1.47$ & $0.0987 \pm 0.0006$ & $607 \pm 3$ \\
\hline 1.2 & $\mathrm{R}$ & 0.018 & 404 & 38 & 0.09 & $13.36032 \pm 0.46$ & $0.05647 \pm 1.26$ & $13.36838 \pm 0.46$ & $0.05598 \pm 1.33$ & $0.0748 \pm 0.0004$ & $465 \pm 2$ \\
\hline $\mathbf{3}$ & $\mathrm{C}$ & $<0.001$ & 219 & 333 & 1.52 & $10.37029 \pm 0.70$ & $0.05938 \pm 1.74$ & $10.39303 \pm 0.70$ & $0.05759 \pm 2.20$ & $0.0965 \pm 0.0007$ & $594 \pm 4$ \\
\hline 4.1 & $\mathrm{C}$ & $<0.001$ & 171 & 100 & 0.59 & $9.30360 \pm 0.81$ & $0.06132 \pm 1.92$ & $9.31764 \pm 0.81$ & $0.06008 \pm 2.05$ & $0.1075 \pm 0.0009$ & $658 \pm 5$ \\
\hline 4.2 & $\mathrm{R}$ & 0.398 & 2115 & 30 & 0.01 & $16.97248 \pm 0.39$ & $0.05712 \pm 1.01$ & $17.12296 \pm 0.41$ & $0.05000 \pm 3.14$ & $0.0587 \pm 0.0002$ & $368 \pm 1$ \\
\hline 11 & $\mathrm{R}$ & 0.194 & 1717 & 3 & 0.00 & $19.05388 \pm 0.27$ & $0.05457 \pm 0.83$ & $19.11077 \pm 0.28$ & $0.05217 \pm 1.50$ & $0.0524 \pm 0.0001$ & $329 \pm 1$ \\
\hline 14 & $\mathrm{R}$ & 0.605 & 3308 & 30 & 0.01 & $19.10956 \pm 0.19$ & $0.05782 \pm 0.58$ & $19.21508 \pm 0.20$ & $0.05341 \pm 1.54$ & $0.0520 \pm 0.0001$ & $327 \pm 1$ \\
\hline 18.2 & $\mathrm{R}$ & 0.113 & 1191 & 3 & 0.00 & $18.21227 \pm 0.35$ & $0.05427 \pm 1.09$ & $18.28258 \pm 0.36$ & $0.05117 \pm 2.06$ & $0.0548 \pm 0.0002$ & $344 \pm 1$ \\
\hline 20.1 & $\mathrm{C}$ & 0.161 & 93 & 43 & 0.46 & $6.13281 \pm 0.97$ & $0.07287 \pm 1.82$ & $6.15084 \pm 0.98$ & $0.07042 \pm 2.49$ & $0.1628 \pm 0.0017$ & $972 \pm 9$ \\
\hline 20.2 & $\mathrm{R}$ & $<0.001$ & 1206 & 55 & 0.05 & $12.54605 \pm 0.32$ & $0.05682 \pm 0.85$ & $12.55101 \pm 0.32$ & $0.05650 \pm 0.87$ & $0.0797 \pm 0.0003$ & $495 \pm 2$ \\
\hline
\end{tabular}

All errors are $1 \sigma$

$C$ core, $R$ rim, LA light area

a Uncorrected ratios

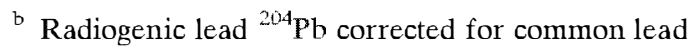

${ }^{0}$ Radiogenic lead ${ }^{207} \mathrm{~Pb}$ corrected for common lead

d ${ }^{207} \mathrm{~Pb}$ corrected for common lead 
Table 2 U-Th-Pb SHRIMP representative analytical data for young zircons from the Anatectic Complex of Toledo

\begin{tabular}{|c|c|c|c|c|c|c|c|c|c|c|c|}
\hline \multicolumn{2}{|c|}{$\begin{array}{l}\text { Spot number } \\
\text { and description }\end{array}$} & $\begin{array}{l}\text { Common } \\
{ }^{206} \mathrm{~Pb}(\%)\end{array}$ & $\mathrm{U}(\mathrm{ppm})$ & Th (ppm) & $\mathrm{Th} / \mathrm{U}$ & ${ }^{238} \mathrm{U} /^{206} \mathrm{~Pb}^{\mathrm{a}}$ & ${ }^{207} \mathrm{~Pb} /{ }^{206} \mathrm{~Pb}^{\mathrm{a}}$ & ${ }^{238} \mathrm{U} /{ }^{206} \mathrm{~Pb}^{\mathrm{b}}$ & ${ }^{207} \mathrm{~Pb} /{ }^{206} \mathrm{~Pb}^{\mathrm{b}}$ & ${ }^{206} \mathrm{~Pb} /{ }^{238} \mathrm{U}^{\mathrm{c}}$ & ${ }^{206} \mathrm{~Pb} /{ }^{238} \mathrm{U}^{\mathrm{d}}$ age \\
\hline \multicolumn{12}{|c|}{$\begin{array}{l}\text { Anatectic complex of Toledo } \\
\text { Sample CV-1 }\end{array}$} \\
\hline 1.1 & $\mathrm{C}$ & 0.239 & 171 & 60 & 0.35 & $10.47344 \pm 0.81$ & $0.06148 \pm 1.99$ & $10.47344 \pm 0.81$ & $0.06148 \pm 1.99$ & $0.0953 \pm 0.0008$ & $587 \pm 5$ \\
\hline 1.2 & $\mathrm{R}$ & $<0.001$ & 1080 & 9 & 0.01 & $19.16364 \pm 0.41$ & $0.05289 \pm 1.30$ & $19.17982 \pm 0.41$ & $0.05221 \pm 1.45$ & $0.0522 \pm 0.0002$ & $328 \pm 1$ \\
\hline 2.1 & $\mathrm{C}$ & 0.215 & 232 & 196 & 0.84 & $19.68903 \pm 0.80$ & $0.05450 \pm 2.51$ & $19.75187 \pm 0.82$ & $0.05193 \pm 3.67$ & $0.0507 \pm 0.0004$ & $319 \pm 3$ \\
\hline 2.2 & $\mathrm{R}$ & 0.123 & 1178 & 9 & 0.01 & $19.19252 \pm 0.35$ & $0.05395 \pm 1.08$ & $19.24001 \pm 0.35$ & $0.05196 \pm 1.57$ & $0.0520 \pm 0.0002$ & $327 \pm 1$ \\
\hline 4.2 & $\mathrm{R}$ & 0.026 & 1303 & 12 & 0.01 & $20.88194 \pm 0.30$ & $0.05257 \pm 1.10$ & $20.88194 \pm 0.30$ & $0.05257 \pm 1.10$ & $0.0479 \pm 0.0002$ & $301 \pm 1$ \\
\hline 4.3 & $\mathrm{R}$ & 0.143 & 457 & 4 & 0.01 & $14.05159 \pm 0.57$ & $0.05691 \pm 1.58$ & $14.03737 \pm 0.57$ & $0.05773 \pm 1.57$ & $0.0711 \pm 0.0004$ & $443 \pm 3$ \\
\hline 5.1 & $\mathrm{C}$ & $<0.001$ & 582 & 713 & 1.22 & $19.67172 \pm 0.52$ & $0.05257 \pm 1.65$ & $19.70370 \pm 0.52$ & $0.05126 \pm 1.77$ & $0.0508 \pm 0.0003$ & $320 \pm 2$ \\
\hline 5.2 & $\mathrm{R}$ & $<0.001$ & 1347 & 10 & 0.01 & $20.29687 \pm 0.30$ & $0.05208 \pm 0.96$ & $20.30026 \pm 0.30$ & $0.05195 \pm 0.98$ & $0.0493 \pm 0.0002$ & $310 \pm 1$ \\
\hline 9.1 & $\mathrm{C}$ & $<0.001$ & 967 & 846 & 0.87 & $19.86282 \pm 0.40$ & $0.05263 \pm 1.29$ & $19.90751 \pm 0.41$ & $0.05082 \pm 1.89$ & $0.0504 \pm 0.0002$ & $317 \pm 1$ \\
\hline 9.2 & $\mathrm{R}$ & 1.082 & 3297 & 18 & 0.01 & $19.26316 \pm 0.21$ & $0.06157 \pm 0.66$ & $19.49025 \pm 0.22$ & $0.05219 \pm 2.70$ & $0.0514 \pm 0.0001$ & $323 \pm 1$ \\
\hline 11.2 & $\mathrm{R}$ & 0.028 & 1276 & 8 & 0.01 & $19.42028 \pm 0.31$ & $0.05311 \pm 0.98$ & $19.43041 \pm 0.31$ & $0.05269 \pm 1.01$ & $0.0515 \pm 0.0002$ & $324 \pm 1$ \\
\hline 14.1 & $\mathrm{C}$ & 0.426 & 570 & 112 & 0.20 & $20.20799 \pm 0.50$ & $0.05599 \pm 1.56$ & $20.27538 \pm 0.54$ & $0.05332 \pm 3.46$ & $0.0493 \pm 0.0003$ & $310 \pm 2$ \\
\hline 14.2 & $\mathrm{R}$ & $<0.001$ & 1407 & 9 & 0.01 & $19.92315 \pm 0.33$ & $0.05225 \pm 1.07$ & $19.93554 \pm 0.33$ & $0.05175 \pm 1.13$ & $0.0502 \pm 0.0002$ & $316 \pm 1$ \\
\hline \multicolumn{12}{|c|}{ Sample LY-1 } \\
\hline 2.1 & $\mathrm{C}$ & $<0.001$ & 132 & 79 & 0.60 & $7.58833 \pm 0.86$ & $0.06406 \pm 1.87$ & $7.59408 \pm 0.86$ & $0.06343 \pm 1.97$ & $0.1321 \pm 0.0012$ & $800 \pm 7$ \\
\hline 2.2 & $\mathrm{R}$ & 0.100 & 507 & 2 & 0.00 & $21.03318 \pm 0.50$ & $0.05312 \pm 1.61$ & $21.05987 \pm 0.50$ & $0.05210 \pm 1.84$ & $0.0475 \pm 0.0002$ & $299 \pm 2$ \\
\hline 8 & $\mathrm{C}$ & $<0.001$ & 223 & 354 & 1.59 & $9.88682 \pm 0.67$ & $0.05938 \pm 1.59$ & $9.89983 \pm 0.67$ & $0.05830 \pm 1.67$ & $0.1013 \pm 0.0007$ & $622 \pm 4$ \\
\hline 9.1 & $\mathrm{C}$ & 0.527 & 411 & 580 & 1.41 & $6.76334 \pm 0.60$ & $0.07290 \pm 0.98$ & $6.78335 \pm 0.61$ & $0.07046 \pm 1.64$ & $0.1471 \pm 0.0009$ & $885 \pm 5$ \\
\hline 9.2 & $\mathrm{R}$ & 0.303 & 405 & 6 & 0.02 & $12.33088 \pm 0.49$ & $0.05971 \pm 1.30$ & $12.34797 \pm 0.49$ & $0.05859 \pm 1.67$ & $0.0809 \pm 0.0004$ & $501 \pm 2$ \\
\hline 10 & $\mathrm{C}$ & 0.084 & 79 & 48 & 0.61 & $9.10993 \pm 1.10$ & $0.06259 \pm 2.57$ & $9.12235 \pm 1.11$ & $0.06148 \pm 2.80$ & $0.1097 \pm 0.0013$ & $671 \pm 7$ \\
\hline 19.1 & $\mathrm{C}$ & 0.062 & 94 & 68 & 0.73 & $8.91629 \pm 1.04$ & $0.06282 \pm 2.39$ & $8.92683 \pm 1.04$ & $0.06185 \pm 2.58$ & $0.1121 \pm 0.0012$ & $685 \pm 7$ \\
\hline 19.2 & $\mathrm{R}$ & 0.010 & 527 & 2 & 0.00 & $21.11044 \pm 0.55$ & $0.05237 \pm 1.81$ & $21.16582 \pm 0.55$ & $0.05027 \pm 2.19$ & $0.0474 \pm 0.0003$ & $298 \pm 2$ \\
\hline 23 & $\mathrm{R}$ & 0.014 & 385 & 2 & 0.01 & $18.85417 \pm 0.67$ & $0.05322 \pm 2.31$ & $18.93643 \pm 0.69$ & $0.04971 \pm 3.76$ & $0.0530 \pm 0.0004$ & $333 \pm 2$ \\
\hline \multicolumn{12}{|c|}{ Sample M-3 } \\
\hline 3 & $\mathrm{C}$ & 0.016 & 1340 & 741 & 0.55 & $10.44415 \pm 0.28$ & $0.05974 \pm 0.60$ & $10.44519 \pm 0.28$ & $0.05966 \pm 0.61$ & $0.0957 \pm 0.0003$ & $589 \pm 2$ \\
\hline 6.2 & $\mathrm{R}$ & 0.537 & 482 & 10 & 0.02 & $14.12987 \pm 0.54$ & $0.06000 \pm 1.66$ & $14.23613 \pm 0.61$ & $0.05395 \pm 4.96$ & $0.0704 \pm 0.0004$ & $439 \pm 2$ \\
\hline 8.1 & $\mathrm{C}$ & $<0.001$ & 75 & 79 & 1.06 & $10.05589 \pm 1.18$ & $0.05964 \pm 4.02$ & $10.13329 \pm 1.24$ & $0.05334 \pm 7.45$ & $0.0995 \pm 0.0012$ & $612 \pm 7$ \\
\hline 8.2 & $\mathrm{R}$ & 0.383 & 547 & 2 & 0.00 & $21.49544 \pm 0.73$ & $0.05523 \pm 2.41$ & $21.52472 \pm 0.74$ & $0.05414 \pm 2.87$ & $0.0463 \pm 0.0004$ & $292 \pm 2$ \\
\hline 9.1 & $\mathrm{C}$ & 0.018 & 142 & 27 & 0.19 & $10.15824 \pm 0.88$ & $0.06019 \pm 2.18$ & $10.18709 \pm 0.88$ & $0.05787 \pm 2.33$ & $0.0984 \pm 0.0009$ & $605 \pm 5$ \\
\hline 9.2 & $\mathrm{R}$ & 0.475 & 352 & 9 & 0.02 & $21.77494 \pm 1.32$ & $0.05587 \pm 4.42$ & $22.21670 \pm 1.57$ & $0.03967 \pm 19.18$ & $0.0457 \pm 0.0006$ & $288 \pm 4$ \\
\hline 13.2 & $\mathrm{R}$ & 0.353 & 418 & 1 & 0.00 & $14.89556 \pm 0.66$ & $0.05798 \pm 1.92$ & $14.94304 \pm 0.66$ & $0.05541 \pm 2.39$ & $0.0669 \pm 0.0005$ & $417 \pm 3$ \\
\hline 13.1 & $\mathrm{C}$ & $<0.001$ & 866 & 205 & 0.24 & $6.44436 \pm 0.32$ & $0.06912 \pm 0.64$ & $6.44732 \pm 0.32$ & $0.06874 \pm 0.68$ & $0.1554 \pm 0.0005$ & $931 \pm 3$ \\
\hline
\end{tabular}

All errors are $1 \sigma$

$C$ core, $R$ rim

a Uncorrected ratios

b Radiogenic lead ${ }^{204} \mathrm{~Pb}$ corrected for common lead

${ }^{c}$ Radiogenic lead ${ }^{207} \mathrm{~Pb}$ corrected for common lead

d ${ }^{207} \mathrm{~Pb}$ corrected for common lead 
Table 3 U-Th-Pb SHRIMP analytical data for old zircons from the Anatectic Complexes of Sotosalbos and Toledo

\begin{tabular}{|c|c|c|c|c|c|c|c|c|c|c|}
\hline $\begin{array}{l}\text { Spot number } \\
\text { and description }\end{array}$ & $\begin{array}{l}\text { Common } \\
{ }^{206} \mathrm{~Pb}(\stackrel{0}{1})\end{array}$ & $\mathrm{U}(\mathrm{ppm})$ & Th (ppm) & $\mathrm{Th} / \mathrm{U}$ & ${ }^{207} \mathrm{~Pb}^{*}{ }^{206} \mathrm{~Pb}^{*}, \mathrm{a}$ & ${ }^{207} \mathrm{~Pb}^{*} / 235 \mathrm{U}^{\mathrm{b}}$ & ${ }^{206} \mathrm{~Pb}^{*}{ }^{238} \mathrm{U}^{\mathrm{b}}$ & $\begin{array}{l}\text { Error } \\
\text { correlation }\end{array}$ & $\begin{array}{l}{ }^{207} \mathrm{~Pb} /{ }^{206} \mathrm{~Pb}^{\mathrm{b}} \\
\text { age }\end{array}$ & $\begin{array}{l}\text { Discordant } \\
(\%)\end{array}$ \\
\hline \multirow{2}{*}{\multicolumn{11}{|c|}{$\begin{array}{l}\text { Anatectic complex of Sotosalbos } \\
\text { Sample } 100.56[\end{array}$}} \\
\hline & & & & & & & & & & \\
\hline 13.1 & 0.17 & 467 & 88 & 0.19 & $0.0824 \pm 0.8$ & $2.37 \pm 0.9$ & $0.2085 \pm 0.5$ & 0.522 & $1256 \pm 15$ & 3 \\
\hline \multicolumn{11}{|l|}{ Sample 100943} \\
\hline 18.1 & $<0.01$ & 80 & 56 & 0.70 & $0.1315 \pm 1.7$ & $7.41 \pm 2.0$ & $0.4088 \pm 1.0$ & 0.512 & $2118 \pm 29$ & -4 \\
\hline \multicolumn{11}{|c|}{ Anatectic complex of Toledo } \\
\hline \multicolumn{11}{|c|}{ Sample CV -1} \\
\hline 4.1 & 2.08 & 144 & 78 & 0.54 & $0.1072 \pm 1.1$ & $3.74 \pm 1.4$ & $0.2527 \pm 1.0$ & 0.680 & $1753 \pm 19$ & 21 \\
\hline 11.1 & 0.95 & 348 & 159 & 0.46 & $0.1362 \pm 0.5$ & $7.18 \pm 0.8$ & $0.3824 \pm 0.6$ & 0.767 & $2180 \pm 9$ & 4 \\
\hline 15 & 2.37 & 52 & 29 & 0.57 & $0.1809 \pm 4.4$ & $11.84 \pm 4.6$ & $0.4748 \pm 1.3$ & 0.283 & $2661 \pm 73$ & 6 \\
\hline \multicolumn{11}{|l|}{ Sangle LY-1 } \\
\hline 26.1 & 1.26 & 47 & 6 & 0.13 & $0.1869 \pm 1.0$ & $13.08 \pm 1.6$ & $0.5076 \pm 1.3$ & 0.772 & $2715 \pm 17$ & 3 \\
\hline \multicolumn{11}{|l|}{ Sannfle M-3 } \\
\hline 6.1 & $<0.01$ & 108 & 69 & 0.64 & $0.1384 \pm 0.8$ & $7.99 \pm 1.2$ & $0.4185 \pm 0.9$ & 0.716 & $2208 \pm 15$ & -2 \\
\hline 10.1 & $<0.01$ & 29 & 55 & 1.95 & $0.2258 \pm 2.1$ & $19.11 \pm 2.6$ & $0.6138 \pm 1.6$ & 0.599 & $3023 \pm 34$ & -2 \\
\hline
\end{tabular}

All errors are $1 \sigma$

C core

* Radiogenic lead

a Uncorrected ratio

${ }^{\mathrm{b}}$ Radiogenic lead ${ }^{204} \mathrm{~Pb}$ corrected for common lead 

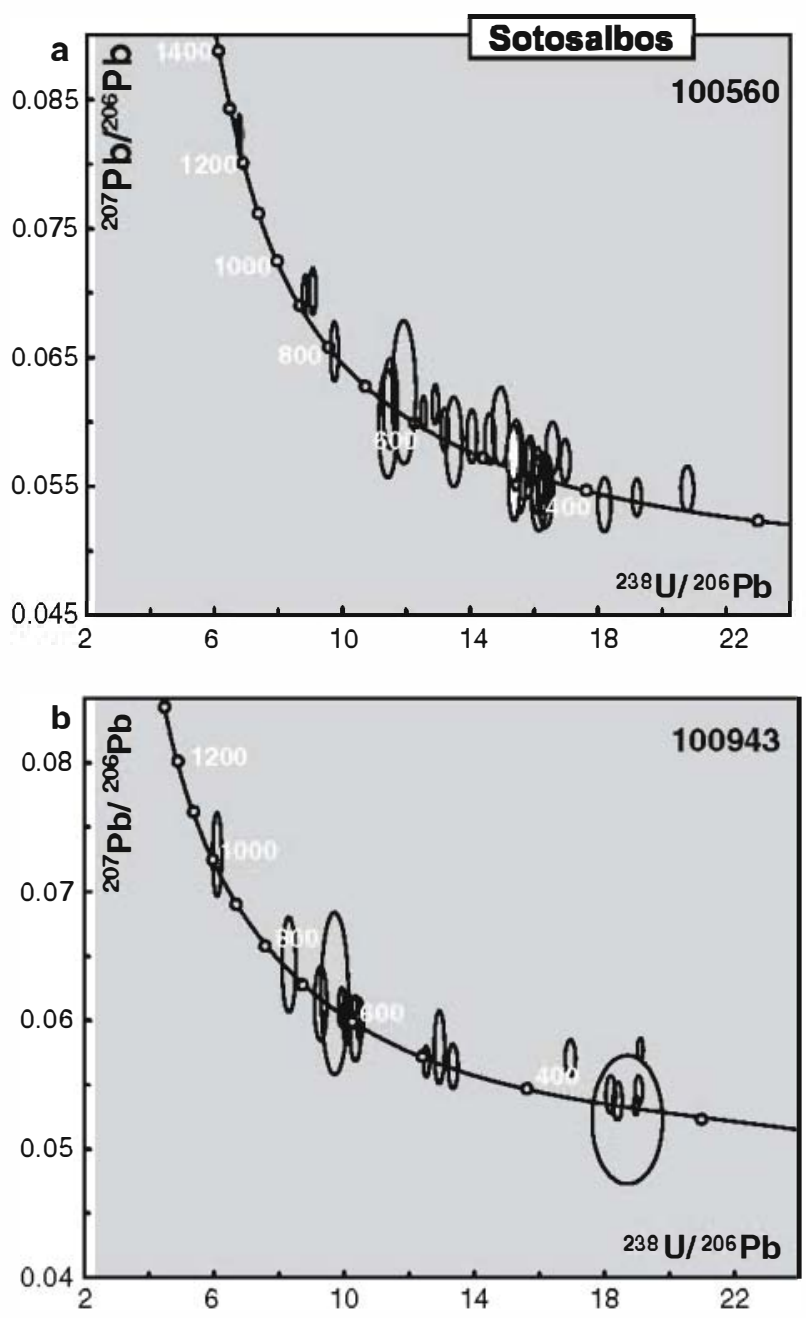

Fig. 4 Tera-Wasserburg plot showing distribution of SHRIMP $\mathrm{U}-\mathrm{Pb}$ zircon ages in samples from Sotosalbos, a sample 100560 , white ellipses represent the data considered to obtain the mean age of the Ordovician magmatism, b sample 100943, where a Paleoproterozoic analysis is not shown. Error ellipses are $\pm 2 \sigma$

are obtained from narrow rims in some grains with low $\mathrm{Th} / \mathrm{U}$ ratios, and they could represent a zircon formation event at $-440 \mathrm{Ma}$. Finally, Hercynian ages are very scarce, and they are obtained in dark irregular rims, ranging from -335 to $-390 \mathrm{Ma}$. This dispersion will be discussed further on.

Results in sample 100943 are slightly different (Figs. 4,6). In this case, only three groups of ages can be distinguished. The predominant group is represented by seven analyses and corresponds to dark rims yielding an approximate mean age of $330 \mathrm{Ma}$ although a minor dispersion of ages, from 327 to $368 \mathrm{Ma}$ is observed. The next group is composed of three analyses in magmatic zones (two rims and one core) that clump together, giving an approximate age of $480 \mathrm{Ma}$. Finally, seven xenocrystic cores
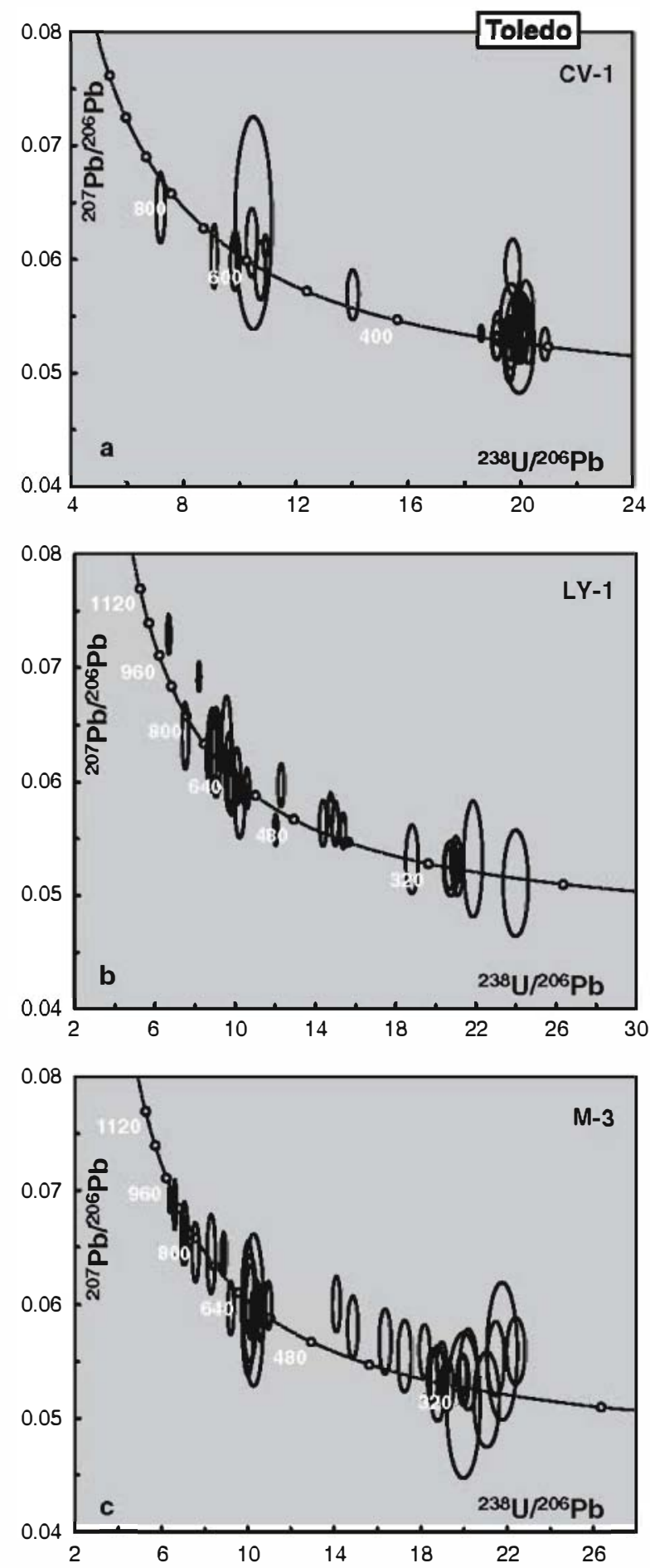

Fig. 5 Tera-Wasserburg plot showing distribution of SHRIMP zircon analyses in samples from Toledo, a CV-1 (anatectic leucogranite), b LY-1 (restite-rich granite), and c M-3 (granite). Older inherited analyses are not shown. Error ellipses are $\pm 2 \sigma$

yield Neoproterozoic ages (600-730 and -970 Ma) and there is also an Early Proterozoic data $(-2,120 \mathrm{Ma})$. 
Fig. 6 Relative probability plots for a Sotosalbos and b Toledo. The main ages discussed in the text are highlighted
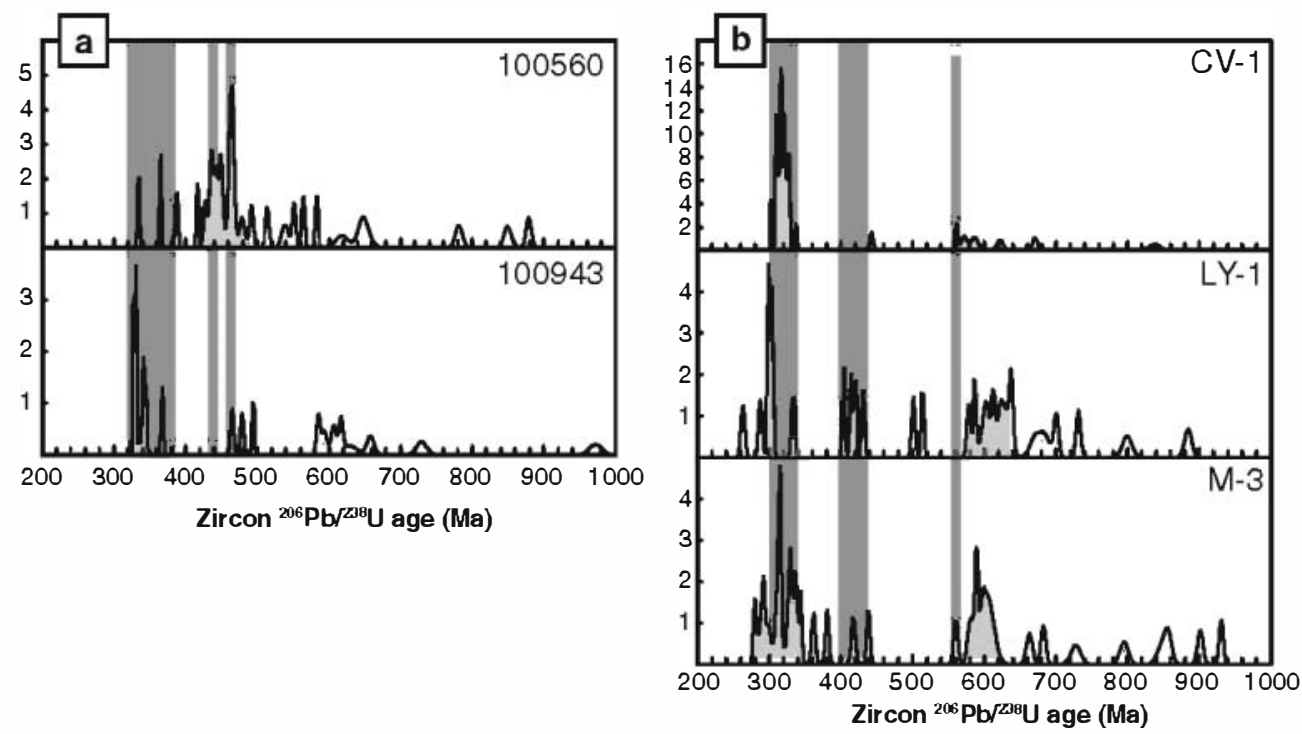

Anatectic complex of Toledo (ACT)

Results in leucogranite CV-1 are dominated by Hercynian ages ( $-300-340 \mathrm{Ma})$; whereas, just one-third of the analysis yield inherited ages (Figs. 5, 6). This inheritance is mainly of Neoproterozoic age $(-560$ $670 \mathrm{Ma})$, with some scattered results at $-440,-840$, $-2,180$ and $-2,660 \mathrm{Ma}$. Hercynian ages are obtained not only in rims but also in apparently xenocrystic cores, suggesting that different Hercynian episodes of zircon growth existed (Fig. 3, zircon grains 2, 5, 9 and 14). Those texturally discordant cores could be the result of a zircon recrystallization during the magmatic (anatectic) event that could have disturbed the isotopic content of older zircons; however, in some grains no evidence of such recrystallization was found (Fig. 3, zircon grain 2). Therefore, we consider that they represent distinct zircon growth events. In order to pinpoint their age, we plot separately rim and core data in a probability density diagram, where several groups of ages can be observed (Fig. 7a) in a wide range (310$330 \mathrm{Ma})$.

In samples LY-1 and M-3, the inherited xenocrystic cores are better preserved and resulted in a wider spectrum of ages (Fig. 6). The distribution of inheritance is similar in both samples, and it resembles the faint distribution obtained in sample $\mathrm{CV}-1$, suggesting that the metasedimentary protolith is equivalent in all the ACT samples (Fig. 6). The predominant group of inherited ages ranges from -560 to $-650 \mathrm{Ma}$ and some scarce older Neoproterozoic ages can be found ( -660 $730 \mathrm{Ma}$ and $-800-930 \mathrm{Ma}$ ). In addition, Late Proterozoic and Archean ages are obtained in three cores $(-2,200,-2,700$ and $-3,000 \mathrm{Ma})$. Despite the high common lead content in some of the inherited cores, these ages are considered significant as concordance is greater than $90 \%$. Another group of ages is obtained from dark, low $\mathrm{Th} / \mathrm{U}$ rims, and the results cluster around $425 \mathrm{Ma}$. Finally, two ages of $-510 \mathrm{Ma}$ are only found in sample LY-1. The Hercynian ages in these samples are also distributed over a wide time span. In sample LY-1, some scarce dark zircon tips (and a dark prism) yield ages from -260 to $-330 \mathrm{Ma}$, with a cluster of four analysis at $301.2 \pm 4.6 \mathrm{Ma}(\mathrm{MSWD}=3.3$ ). In sample M-3, Hercynian rims are more abundant ranging in age from -280 to $-360 \mathrm{Ma}$, with a peak at $314.2 \pm 1.9 \mathrm{Ma}(\mathrm{MSDW}=0.94)$.

\section{Interpretation and discussion of the results}

Age and nature of pre-migmatitic protoliths

In the ACS, the good preservation of pre-Hercynian zircons in the granites is remarkable even though the original orthogneissic fabric has been mostly obliterated during the Hercynian anatectic event. More than the $85 \mathrm{vol} \%$ of the zircon crystals was inherited from the protolith as restitic minerals, and they resisted events of $700-800^{\circ} \mathrm{C}$ without major recrystallization. Considering the biggest population of youngest magmatic zircons, a concordia age of $464 \pm 2.6 \mathrm{Ma}$ can be obtained in sample 100560; whereas, in sample 100943, three analyses yield an approximate age of $-480 \mathrm{Ma}$. Both ages are in agreement with previously published $\mathrm{U}-\mathrm{Pb}$ and $\mathrm{Rb}-\mathrm{Sr}$ ages in Guadarrama orthogneisses (Vialette et al. 1987; Wildberg et al. 1989; ValverdeVaquero and Dunning 2000). Nevertheless, recently 

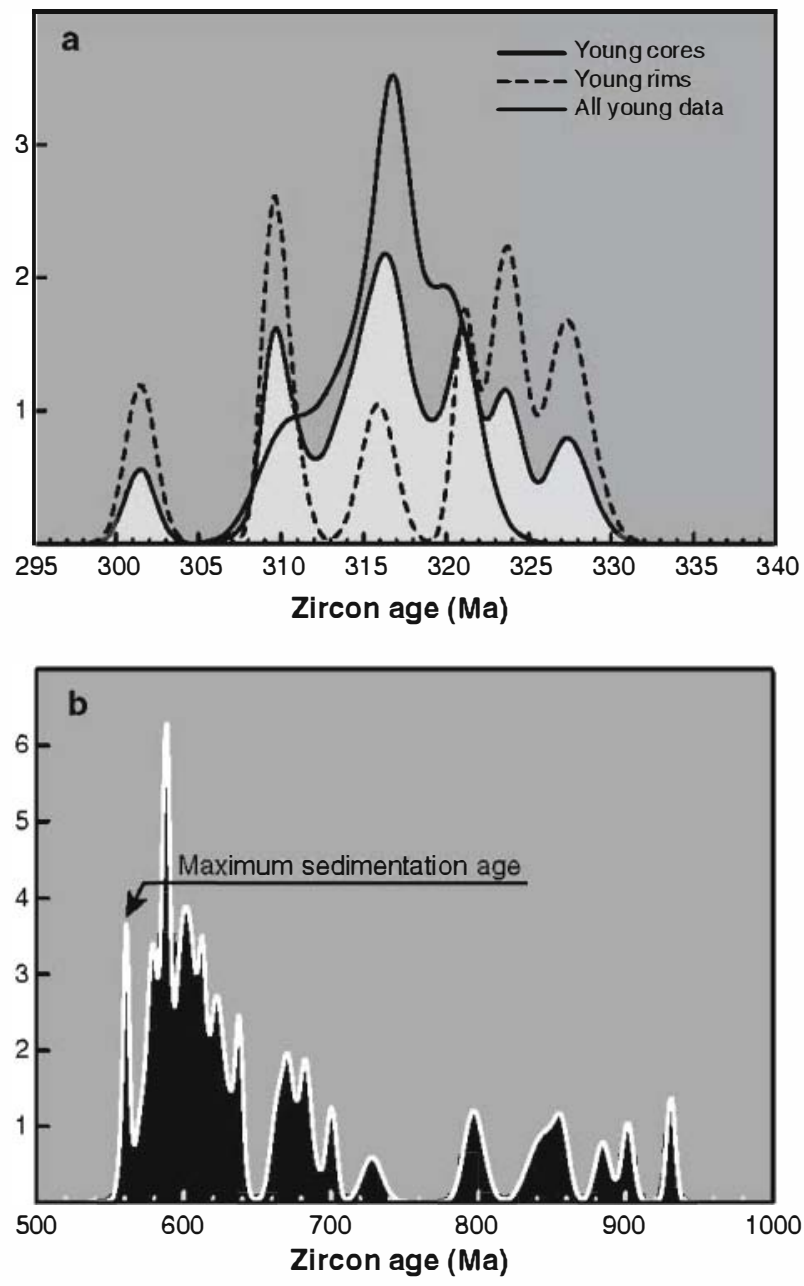

Fig. 7 Relative probability plots showing a possible episodes of zircon growth recognized in sample CV-1 and $\mathbf{b}$ the minimum age of detrital zircons in all the samples from Toledo represents the maximum age of the deposition of the sedimentary protolith

dated augen orthogneissic samples from the western part of the SCS yield ages from 546 to $525 \mathrm{Ma}$ (SHRIMP in zircon, Zeck et al. 2004, and single-crystal evaporation in zircon, Bea et al. 2003) evidencing a marked diachronism of this Lower Paleozoic felsic peraluminous magmatism in the SCS. This diachronism is a common feature in the Hercynian complexes of Central Europe (e.g. Finger et al. 2000, and references therein). Cocherie et al. (2005) propose that the protracted and intense magmatic activity characterizing the basement of the southern European terranes, when compared to the northern Gondwana margin, supports a possible individualization of these terranes before Ordovician times.

The preservation of inherited ages in the pelite-derived Toledo migmatites also suggests that zircon recrystallization during partial melting events is less effective than previously supposed in melt-rich migmatites (e.g. Nemchin et al. 2001; Villaseca et al. 2003; Moecher et al. 2004), and that zircon is mainly incorporated as restitic material, with only minor precipitation of zircon during melting. Additionally, the scatter in the Hercynian ages shown in Fig. 4 suggests that isotopic equilibrium is hardly attained in anatectic melts during the new zircon growth event due to the incomplete dissolution of inherited zircon grains. A similar effect was previously described in the $\mathrm{Sr}-\mathrm{Nd}$ isotope systematics from the same rocks (Barbero et al. 1995). However, due to the thinness of some zircon rims, it is possible that the scattered Hercynian data are mixed ages as a result of hitting older domains.

The ages recorded in zircon grains from ACT granites should be significant in characterizing the sources of the sedimentary protolith and in estimating its depositional age. In this way, when plotting the ages of the detrital grains from the ACT samples (Fig. 7b), we can assume that the minimum age of $-560 \mathrm{Ma}$ represents the maximum depositional age for the sedimentary protolith (Nelson 2001). This age coincides with the estimated stratigraphic age of the Ibor-Navalpino Group (Rodríguez Alonso et al. 2004) to which they supposedly could be correlated.

The presence of a single Mesoproterozoic age is incompatible with the accepted idea of a "Mesoproterozoic gap" typical of Gondwana sediments with West African sources as occurs in other European Hercynian terranes (e.g. Kober et al. 2004), and in contrast to sources which exhibit Mesoproterozoic detrital zircon populations from the Amazonian craton (Friedl et al. 2000). The singularity of this Mesoproterozoic age ( 1,260 Ma obtained from the Sotosalbos granite) could have led us to doubt its geological significance on the basis of the accepted paleogeographic models and to reject this "anomalous" analysis arguing the possible existence of Pb-loss. However, Sánchez Martínez et al. (2006) have found a piece of a $-1,160 \mathrm{Ma}$ ophiolite involved in the Hercynian suture of NW Spain, suggesting that pieces of Mesoproterozoic crust were incorporated to the West African terranes during the assembly of Rodinia, giving a geological significance to our single Mesoproterozoic age.

Finally, a group of analyses in thin dark rims (low in $\mathrm{Th} / \mathrm{U}$ ratios) cluster around $440-425 \mathrm{Ma}$ in samples from both anatectic complexes. Low $\mathrm{Th} / \mathrm{U}$ ratios are commonly interpreted as the consequence of a metamorphic event (Hoskin and Black 2000). However, the lack of geological evidence in the studied area supporting any metamorphic event at that age suggests that they could represent mixed ages between thin rims and cores. 
4.5 kb, Martín Romera et al. 1999) confirm that after

$P-T$ paths in high-grade terranes of the Central Iberian Zone suggest that migmatization occurs in the low- $\mathrm{P}$ part of the $P-T$ evolution after peak $P-T$ conditions have been attained. This is well illustrated in the Tormes gneiss dome (Fig. 1) and in the eastern SCS domain (where ACS crops out), where complete $P-T$ paths have been established (Escuder Viruete et al. 2000; Barbero and Villaseca 2000). In the Tormes gneiss dome, Escuder Viruete et al. (2000) have obtained a $P$ $T$ path with two metamorphic stages: a first compressive phase reaching upper amphibolite facies conditions and a subsequent near-isothermal decompression episode during which a high-T fabric was developed and local partial melting occurred (Fig. 8). In the SCS, the first Hercynian tectonothermal stage $\left(\mathrm{M}_{1}\right)$ could reach eclogite conditions, but was only preserved in some metabasic layers (Barbero and Villaseca 2000). This is followed by an exhumation stage with pressure differences of around 9-10 kb from peak pressure conditions of $-14 \mathrm{~kb}$ until low-pressure re-equilibration at $4-5 \mathrm{~kb}$, when migmatization occurs (Fig. 8). Coronitic mafic granulites interlayered within the augen orthogneisses record an intermediate exhumation stage, giving recrystallization conditions of $830^{\circ} \mathrm{C}$ and $7-8 \mathrm{~kb}$, (Villaseca et al. 2002). Finally, $P-T$ conditions obtained for the migmatization in Sotosalbos area $\left(725^{\circ} \mathrm{C}\right.$ and the metamorphic peak, some cooling took place during exhumation. $P-T$ paths intersect biotite-breakdown reactions at low pressure and decreasing temperature although the exact locus of the intersection depends on the whole-rock chemistry (Fig. 8).

In other migmatitic areas (Peña Negra or Toledo), $P-T$ paths are not complete; however, the portion of the path deduced from mineral paragenesis in the ACT (Barbero 1995) indicates that migmatization occurred during the low-P evolution of the rocks after peak conditions were surpassed (Fig. 8).

The Hercynian ages obtained in this study are considered to correspond to the migmatization event. The high dispersion in the data from both anatectic areas can be interpreted in two ways. On one hand, the dispersion could have been isotopically influenced by the partial dissolution of inherited zircons. This interpretation is supported by the abundance of old zircons and the disequilibrium observed in whole-rock geochemistry and isotopic systems (Barbero et al. 1995). On the other hand, the recognition of different growth stages (Figs. 4, 7a) can be explained as the result of a protracted migmatitic event. A similar interpretation has been proposed to explain the ages obtained in the Peña Negra complex (Bea et al. 2003) and other migmatitic complexes (e.g. Finger and Clemens 1995; Keay et al. 2001; Tropper et al. 2006). Nevertheless, it is
Fig. $8 P-T-t$ paths from different migmatitic areas in the Central Iberian Zone. Tormes Gneiss Dome path after Escuder Viruete et al. (2000); Guadarrama path after Escuder Viruete et al (1998) and Villaseca and Ubanell (2005); Sotosalbos path after Barbero and Villaseca (2000); and Toledo path after Barbero (1995).

Petrogenetic grid after Spear et al. (1999)

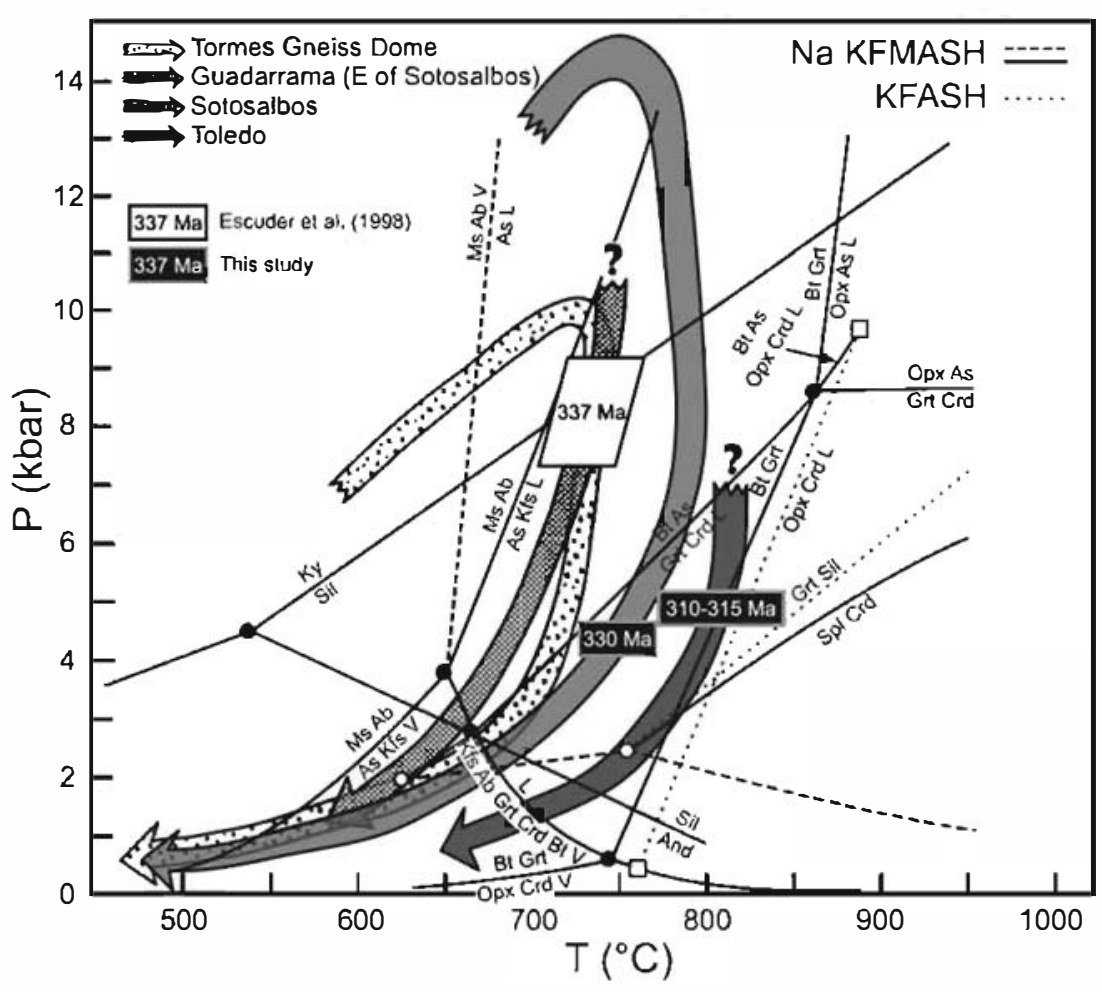


possible that a combination of both processes occurred, evidencing the complex evolution in these anatectic areas. In the ACS, taking into account the scarcity of new zircon growth during the anatectic event and the influence of inherited zircons, we interpret that the dispersion of the Hercynian ages is the result of an incomplete isotopic re-equilibration with inherited zircon domains. Therefore, we consider $-330 \mathrm{Ma}$ as the most probable age for the migmatization in the Sotosalbos area.

In the ACT, the main zircon growth has been dated at $-317 \mathrm{Ma}$ although other episodes of zircon growth could have occurred at -300 and -325 Ma. In sample $\mathrm{CV}-1$, the age dispersion could be the result of different zircon growth episodes during a long migmatitic event; however, in sample M-3, the trends defined in the concordia plot suggest that younger ages than $-315 \mathrm{Ma}$ could have been affected by lead loss; whereas, older ages could be the result of incomplete isotopic equilibration.

In any case, diachronism between both anatectic areas can be observed, and it reflects the complexity of the migmatization event in the waning stages of the Hercynian orogenesis. Recently, Bea et al. (2006) present new results in two migmatite samples from the ACT. They propose an age for the migmatization surprisingly older (332 Ma). However, the age interval they obtained is similar to our data ( 350 to $320 \mathrm{Ma}$ ), suggesting that their older age could be biased due to a limited dataset (14 versus our 50 analyses) and poses the question of which would be the minimum amount of analyses necessary to properly characterize complex geologic processes like long-lived migmatization events similar to the one described in Montero et al. (2004). It is also noteworthy that our youngest migmatization ages overlap the age of the mafic magmatism from the Toledo area obtained by Bea et al. (2006). Nevertheless, new additional data and future geochronological work are needed to clarify this discussion.

The age of the migmatization is slightly younger than the estimated age for the extensional event in the SCS, which supposedly occurred between 337 and $332 \mathrm{Ma}$, based on textural relationships and $\mathrm{U}-\mathrm{Pb}$ dating of accessory phases (Galibert 1984; Escuder Viruete et al. 1998). This is in agreement with the petrologic evidence suggesting that anatexis took place late in the Hercynian cycle during the exhumation of metamorphic core complexes (Barbero 1995).

This late origin with respect to the thermal peak for the studied migmatite terranes in the Central Iberian Zone is also comparable with other European Hercynian terranes, where ages for intermediate-P and high$\mathrm{T}$ granulites vary from 345 to $330 \mathrm{Ma}$ (Kröner et al.
1998; Chen et al. 2003; Gordon et al. 2005). In the southeast of the French Massif Central, migmatization has been dated between 329 and 323 Ma (Be Mezeme et al. 2006), closer in ages to those exposed in this work. Nevertheless, two successive high-T events have been described in the Velay anatectic dome (French Massif Central), the youngest (at $-305 \mathrm{Ma}$ ) being responsible for most of the cordierite-bearing granites which characterize this dome (Ledru et al. 2001).

\section{Relationships with plutonic granitoids}

Most of the geochronological data on Hercynian plutonic magmatism from the Central Iberian Zone indicate that the major volume of granites was emplaced during the $\mathrm{D}_{3}$ ductile deformation phase at 320 310 Ma (Dias et al. 1998; Fernández Suárez et al. 2000; Valle-Aguado et al. 2005). Migmatite complexes from the eastern SCS (e.g. Sotosalbos) are not spatially related to allochtonous syn-intrusive granites. Peraluminous granites intrude later in these migmatite areas which are consequently cooled, and typical aureolecontact metamorphism develops related to the epizonal emplacement of those undeformed granite plutons, mostly in the age range of 310-285 Ma (Villaseca et al. 1995; Casquet et al. 2004). For this reason, the SCS granite batholith appears mostly discordant with the regional metamorphic structures, and thus is considered as post-metamorphic granites (e.g. Villaseca et al. 1995). This situation is similar to that described in the southern part of the French Massif Central, where late-Hercynian plutonic granites are mostly dated from 318 to $311 \mathrm{Ma}$, clearly intrusive in nearby high- $\mathrm{T} \mathrm{mi-}$ gmatite areas (Be Mezeme et al. 2006).

However, other migmatite complexes from Central Spain show coeval intrusion of plutonic bodies from deeper sources during anatexis. In the ACT, some calk-alkaline basic and acid bodies (Barbero et al. 1990) and S-type granites (Barbero 1992) intrude previously or during regional migmatization. In the nearby Peña Negra complex the presence of peraluminous granodiorites with mafic enclaves is also described which, nevertheless, has been interpreted as subautochthonous plutonic bodies (Pereira and Rodríguez Alonso 2000; Montero et al. 2004).

The presence of more mafic granitoids (Ca-Fe richer monzogranites or granodiorites) than the common eutectic-like composition of melt-rich migmatites (leucosomes and leucogranites) is suggestive of the lower crustal derivation of most of the pluton-size SCS granitoids, either syn- $\mathrm{D}_{3}$ or post- $\mathrm{D}_{3}$ types, in good agreement with geochemical and isotopic balance with residual granulites from SCS xenolith suites (Villaseca 
et al. 1999; Villaseca et al. 2001). Moreover, a recent $\mathrm{U}-\mathrm{Pb}$ geochronological study on those lower crustal xenoliths (Fernández-Suárez et al. 2006) shows that nearly $90 \mathrm{vol} \%$ of the granulitic zircon re-crystallized during the time span of 277-312 Ma, in accordance with ages of exposed granites. Large-scale melting in lower-crustal scenarios seems to be younger than the limited partial melting which occurred in migmatite terranes at mid-crustal levels. Thus, several mid- to lower-crustal layers were partially melted at different times during the late Hercynian period.

\section{Concluding remarks}

The analysis of small areas of composite zoned zircons provided by ion microprobe techniques is the key to elucidating the history of intricate rocks. The coupled CL and geochronological study of zircons in anatectic granites and related rocks is essential to the knowledge on the origin and evolution of the migmatitic complexes. In this study, the two samples analyzed from Sotosalbos give us information about the West African provenance of the former sediments, which were incorporated into a granitic melt at $-460 \mathrm{Ma}$ and subsequently migmatized during the late stages of the Hercynian orogeny. Regarding the three samples analyzed from the Toledo area, the geochronological information obtained also includes the West African provenance of the sedimentary protolith, and its maximum depositional age $(-560 \mathrm{Ma})$ can be deduced from the detrital zircon population. The complexity of the Hercynian metamorphism is evident in the dispersion of the age data and can be the result either of an isotopic disequilibrium and subsequent disturbance of the system, or the existence of a protracted migmatitic event with at least three episodes of zircon precipitation. A marked diachronism in anatexis between both migmatite complexes is also evident and lends a late Hercynian age to this crustal re-melting event. Moreover, although several mid- to lower-crustal layers were partially melted at different times during the late Hercynian period, larger-scale melting in lower-crustal scenarios seems to be the most appropriated source for the post-orogenic SCS granite batholith.

Acknowledgments The authors are grateful to the people at SUMAC facility for their assistance during the SHRIMP-RG analytical sessions, especially J. Wooden and F. Mazdab. We also thank J. Gómez-Barreiro for his help during the dating sessions. The preliminary version of this paper was improved thanks to the careful reviews by I. Braun, Ph. Rossi and F. Finger. Ch. Kaas is kindly acknowledged for her help in the English version. This work has been supported by the Spanish Commission for Science and Technology, project CGL2004-02515, and was done while P.C. was holding a Fulbright postdoctoral fellowship at University of Colorado, financed by Spanish Ministerio de. Educación y Ciencia. This work is also included in the objectives of the Consolider-Ingenio 2010 Programme under the project CSD2006-0041 "TOPO-IBERIA". P. C. thanks I. Brownfield, at the USGS-Denver Microbeam Laboratory, for her help during the CL imaging of the zircons. J. Paces, J. Aleinikoff and W. Premo provided the necessary equipment to prepare and image the SHRIMP mounts.

\section{References}

Barbero L (1992) Plutonismo sin-orogénico en un área granulítica Hercínica: el Complejo Anatéctico de Toledo. PhD Thesis, Universidad Complutense de Madrid, pp 1-455

Barbero L (1995) Granulite-facies metamorphism in the anatectic complex of Toledo, Spain: late Hercynian tectonic evolution by crustal extension. J Geol Soc London $152: 365-382$

Barbero L, Villaseca C (1992) The layos granite, hercynian complex of Toledo (Spain): an example of parautochthonous restite-rich granite in a granulitic area. Trans $\mathbf{R}$ Soc Edinburgh. Earth Sci 83:127-138

Barbero L, Rogers G (1999) Implications of U-Pb monazite ages from syn-orogenic granites of the anatectic complex of Toledo (Spain) in the evolution of the central part of the Hercynian Iberian Belt. Doc BRGM 290:203

Barbero L, Villaseca C (2000) Eclogite facies relics in metabasites from the Sierra de Guadarrama (Spanish Central System) $P-T$ estimations and implications for the Hercynian evolution. Min Mag 64:815-836

Barbero L, Villaseca C, Andonaegui P (1990) On the origin of the gabbro-tonalite-monzogranite association from Toledo area (Hercynian Iberian Belt). Schweizerische Mineralogische und Petrografische Mitteilungen 70:207-219

Barbero L, Villaseca C, Rogers G, Brown PE (1995) Geochemical and isotopic disequilibrium in crustal melting: an insight from anatectic +granitoids from Toledo, Spain. J Geophys Res 100:15745-15765

Be Mezeme E, Cocherie A, Faure M, Legendre O, Rossi PH (2006) Electron microprobe monazite geochronology of magmatic events: examples from Variscan migmatites and granitoids, Massif Central, France. Lithos 87:276-288

Bea F, Pereira MD, Stroh A (1994) Mineral/leucosome traceelement partitioning in a peraluminous migmatite (a laser ablation-ICP-MS study). Chem Geol 117:291-312

Bea F, Montero P, Zinger T (2003) The nature, origin, and thermal influence of the granite source layer of Central Iberia. J Geol 111:579-595

Bea F, Montero P, Gonzalez-Lodeiro F, Talavera C, Molina JF, Scarrow JH, Whitehouse MJ, Zinger T (2006) Zircon thermometry and $\mathrm{U}-\mathrm{Pb}$ ion-microprobe dating of the gabbros and associated migmatites of the Variscan Toledo anatectic complex, Central Iberia. J Geol Soc London 163:847-855

Black LP, Kamo SL, Allen CM, Davis DW, Aleinikoff JN, Valley JW, Mundil R, Campbell IH, Korsch RJ, Williams IS, Foudoulis C (2004) Improved ${ }^{206} \mathrm{~Pb} /{ }^{238} \mathrm{U}$ microprobe geochronology by the monitoring of a trace-element-related matrix effect, SHRIMP, ID-TIMS, ELA-ICP-MS and oxygen isotope documentation for a series of zircon standards. Chem Geol 205:115-140 
Casquet C, Montero P, Galindo C, Bea F, Lozano R (2004) Geocronología ${ }^{207} \mathrm{~Pb} /{ }^{206} \mathrm{~Pb}$ en cristal único de circón y $\mathrm{Rb}-\mathrm{Sr}$ del plutón de La Cabrera (Sierra del Guadarrama). Geogaceta 35:71-74

Chappell BW, White AJR (1992) I- and S-type granites in the Lachlan Fold Belt. Trans R Soc Edinb Earth Sci 83:1-26

Chen F, Todt W, Hann HP (2003) Zircon and garnet geochronology of eclogites from the Moldanubian zone of the Black Forest, Germany. J Geol 111:207-222

Cocherie A, Baudin Th, Autran A, Guerrot C, Fanning CM, Laumonier B (2005) U-Pb zircon (ID-TIMS and SHRIMP) evidence for the early Ordovician intrusion of mic (agranditcs in the late Proterozoic Canaveilles Group of the Pyrenees and the Montagne Noire (France). Bull Soc Géol Fr 176:269-282

Dias G, Leterrier J, Mendes A, Simoes PP, Bertrand JM (1998) $\mathrm{U}-\mathrm{Pb}$ zircon and monazite geochronology of post-collisional Hercynian granitoids from the Central Iberian Zone (Northern Portugal). Lithos 45:349-369

Escuder Viruete J, Hernáiz PP, Valverde-Vaquero P, Rodríguez $R$, Dunning $G$ (1998) Variscan syncollisional extension in the Iberian Massif: structural, metamosphic and geochronoIngical evidence from the Somosierra sector of the Sierra de Guadamama (Central Iberian Zone, Spairi). I'cctonophysics 290:87-109

Escuder Viruete J, Indares A, Arenas R (2000) $P-T$ paths derived from parnet growth zoning in an extensional setting: an example from the Tormes Gneiss Dome (Iherian Massif, Spain). J Petrol 41:1489-1515

Fesnández. Suárez J, Dunning GR, Jenner GA, Gutiérrez Alonso $G$ (2000) Variscan collisional magmatism and deformation in NW Iberia: constraints from $\mathrm{U}-\mathrm{Pb}$ geochronology of granitoids. J Geol Soc London 157:565-576

Fernández Suárez J, Arenas R, Jeffries T, Whitehouse MJ, Villaseca C (2006) A U-Pb study of zircons from a lower crustal granulite xenolith of the Spanish Central System: a record of Iberian lithospheric evolution from the Neopro terozoic to the Triassic. J Geol 114:471-483

Finger F, Clemens JD (1995) Mignatization and "secondary" granitic magmas: effects of emplacement and crỵstallization of "primary" granitoids in southern Bohemia, Austria. Contuih Mineral Petrol 120:311-326

Füjuger F, Hanžl P, Pin C, von Quadt A, Steyrer HP (2000) The Brunovistulian: Avalonian Precambrian sequence at the eastern end of the Central European Variscides? In: Franke W, Haak V, Oncken O, Tanner D (eds) Orogenic processes: quantification and modeling in the Variscan Belt. Geological Society, London, Special Publication 179, pp. 103-112

Friedl G, Finger F, McNaughton NJ, Fletcher IR (2000) Deducing the ancestry of terranes: SHRIMP evidence for South America-derived Gondwana fragments in central Europe. Geology 28:1035-1038

Galibert $\Gamma$ (1984) Géchimie et géochronologie du complexe granitique de l'antiforme de Morille (Salamanca, Espapne). Rapport de Stage de DEA Lab Géochimie Isotopique, Iniv Montpellier, pp 1.-53

Gibbons W, Moreno T (2002) The gcology of Spain. Geological Society, London. $649 \mathrm{pp}$

Gordon SM, Schneider DA, Manecki M, Holm DK (2005) Exhumation and metamorphism of an ultrahigh-grade terrane: geochronometric investigations of the Sudetes Mountains (Bohemia), Poland and Czech Republic. J Geol Soc London 162:841-855

Hoskin PWO, Black LP (2000) Metamorphic zircon formation by solid-state recrystallization of protolith igneous zircon. J Metamorphic Geol 18:423-439
Ireland TR, Williams IS (2003) Considerations in zircon geochronology by SIMS. In: Hanchar JM, Hoskin PWO (eds) Zircon. Reviews in mineralogy and geochemistry 53:215-241

Julivert M, Fonboté JM, Ribeiro A, Conde LN (1972) Mapa Tectónico de la Península Ibérica y Baleares E 1:1000000. Instituto Geológico y Minero de España, Madrid

Keay S, Lister G, Buick I (2001) The timing of partial melting, Barrovian metamorphism and gratice intrusion in the Naxos metamontic core complex. Cyclades, Aegean Sea, Greece. I'ectomophysics 342:275-312

Kober B, Kalt A, Hant M, Pidece on RT (2004) SHRIMP dating of zircons from high-grate metasediments of the Schwarzwuald/SW-Germany and implications for the evolution of the Moldanubian basement. Contrib Mineral Petrol 147:330-345

Kröner A, Jaeckel P, Reischmann T, Kroner U (1998) Further evidence for an early Carboniferous ( $340 \mathrm{Ma})$ age of highgrade metamorphism in the Saxonian granulite complex. Geol Runsd 86:751-766

Lancelot JR, Allegret A, Iglesias Ponce de León M (1985) Outline of Upper Precambrian and Lower Jalcostric cwolution of the Iberian Peninsula according to $\mathrm{U}-\mathrm{Pb}$ daritig of zircons. Earth Planet Sci Lett 74:325-337

Ledru P, Courrioux G, Dallain C, Lardeaux JM, Montel JM, Vanderhaeghe O, Vitel G (2001) The Velay dome (French Massif Central): melt generation and granite emplacement during orogenic evolution. Tectonophysics $342: 207 \ldots 2.37$

I udwip KR (2092) SQIIJD 1.02, a user's manual. Berkeley Geochromology Center Special Publication 2, pp 1-17

Ludwig KR (2003) isoploritix, version 3, A Geochronological Toolkit for Microsoft Excel. Berkeley Geochronology Center Special Publication 4, pp 1-71

Martín Romera C, Villaseca C, Barbero L (1999) Materiales anatécticos en el área de Sotosalbos (Segovia, Sierra de Guadarrama). Caracterización petrológica, geoquímica e isotopica (Sr, Nd). Actas II Congreso Ibérico de Geoqui mica Lisboa 329-332

Moecher DP, Samson SD, Miller CF (2004) Precise time and conditions of peak Taconian granulite facies metamornhism in the southern Appalachian orogen, USA, with implica. tions for zircon behaviour during crustal melting events. J Geol 112:289-304

Montero P, Bea F, Zingct TF, Scarrow JH, Molina JF, Whitehouse M (2004) 55 million years of continuous anatexis in Central Iberia: single-zircon dating of the Peña Negra complex. J Geol Soc Lond 161:255-263

Nelson DR (2001) An assessment of the determination of depositional ages for precambrian clastic sedimentary rocks by U-Pb dating of detrital zircons. Sed Geol 141-142:37-60

Nemchin AA, Giannini LM, Bodorkos S, Oliver NHS (2001) Ostwald ripening as a possible mechanism for zircon overgrowths formation during anatexis: theoretical constraints, a numerical model, and its application to pelitic mipmatites of the Tickalara Metamorphics, northwestern Australia. Geochim Cosmochim Acta 65:2771-2788

Pereira MD, Rodrigucz. Alonso MD (2000) Duality of cordierite granites related to melt-restite scorgation in the Peña Negra anatectic complex, Central Spain. Can Mineral 38:1329-1346

Pidgeon RT, Furfaro D, Kennedy AK, Nemchin AA, van Bronswik W (1995) Calibration of zircon standards for the Curtin SHRIMP II. US Geol Survey Circular 1107:251

Rodríguez Alonso MD, Díez Balda MA, Perejon A, Pieren A, I inán E, I opez. Díaz F, Moreno F, Gámez Vintaned JA, González Lodeiro F, Martínez Poyatos D, Vegas R (2004) 
La secuencia lifocstratigráfica del Neoproterozoico-Cámbrico Inferior del Donirio dcl Compalcjo Esquisto-Grauváquico. In: Vera JA (ed) Gcoloyía de Españà fp 78-81

Sánchez Martínez S, Jeffries T, Arenas R, Firnándč-Suárez J, García-Sánchez R (2006) A pre-Rodinian ophiolite envolved in the Variscan suture of Galicia (Cabo Ortegal Complex, NW Spain). J Geol Soc London 163:737-740

Spear FS, Kohn MJ, Cheney JT (1999) $P-T$ paths from anatectic pelites. Contrib Mineral Petrol 134:17-32

Tropper P, Deibl I, Finger F, Kaindl R (2006) P-T-t evolution of spinel-cordierite-garnet gneisses from the Sauwald Zone (Southern Bohemian Massif, Upper Austria): is there evidence for two independent late-Variscan low-P/high- $\mathrm{T}$ events in the Moldanubian Unit? Int J Earth Sci 95:10191037

Valle-Aguado B, Azevedo MR, Schaltegger U, Martínez Catalán JR, Nolan J (2005) U-Pb zircon and monazite geochronology of Variscan magmatism related to syn-convergence extension in central Northern Portugal. Lithos 82:169-184

Valverde-Vaquero P, Dunning GR (2000) New U-Pb ages for Early Ordovician magmatism in Central Spain. J Geol Soc London 157:15-26

Vialette Y, Casquet C, Fúster JM, Ibarrola E, Navidad M, Peinado M, Villaseca C (1987) Geochronological study of the orthogneisses from the Sierra de Guadarrama (Spanish Central System). Neues Jarbuch für Mineralogie Monatshefte H10:465-479

Villaseca C, Ubanell AG (2005) El macizo metagranítica de La Cebollera (Pico de las Tres Provincias, Somosierra, Sistema Central Español): nuevos datos sobre el metamorfismo Hercínico del sector de Somosierra. Rev Soc Geol España 18:115-131
Villaseca C, Eugercios L, Snelling NJ, Huertas MJ, Castellón T (1995) Nuevos datos geocronológicos (Rb-Sr, K-Ar) de granitoides hercínicos de la Sierra de Guadarrama. Rev Soc Geol España 8:129-140

Villaseca C, Downes H, Pin C, Barbero L (1999) Nature and composition of the lower continental crust in central Spain and the granulite-granite linkage: inferences from granulitic xenoliths. J Petrol 40:1465-1496

Villaseca C, Martín Romera C, Barbero L (2901) Melts and residua geochemistry in a low-to-mid crustal section ( $\mathrm{CHT}-$ tral Spain). Phys Chem Earth 26:273-280

Villaseca C, Martín Romera C, Barbero L (2002) Estimaciones termobarométricas en los metagabros coroníticos de la región de Scyovia (Sicra de Guadarrama). Gcopacta 32:11-14

Villaseca C, Martín Romera C, de la Rosa J, Barbero L (2003) Residence and redistribution of REE, $\mathrm{Y}, \mathrm{Zr}$, Th and $\mathrm{U}$ during granulite-facies metamorphism: behaviour of accessory and major phases in peraluminous granulites of central Spain. Chem Geol 200:293-323

Wildberg HGH, Bischoff L, Baumann A (1989) [i-Ph ages of zircons from meta-igneous and metasedimettatyrocks of the Sierra de Guadarrama: implicarions for the Central Iberian crustal evolution. Contrib Mincral Petrol 103:253-262

Williams IS (1997) U-Th-Pb geochronology by ion microprobe: not jusı ages but histories. Econ Geol 7:1-35

Zeck HP, Wingate MTD, Pooley GD, Ugidos JM (2004) A sequence of Pan-African events recorded in zircons from an orthogneiss from the Jiercymian Belt of western Central Iberia- an ion microprobe U-Pb study. J Petrol 45:16131629 


\title{
SHRIMP U-Pb zircon dating of anatexis in high-grade migmatite complexes of Central Spain: implications in the Hercynian evolution of Central Iberia
}

\author{
Pedro Castiñeiras • Carlos Villaseca • \\ Luis Barbero • Cristina Martín Romera
}

\begin{abstract}
U-Pb SHRIMP ages obtained in zircons from the Sotosalbos and Toledo anatectic complexes in Central Spain give new constraints to the evolution of the inner part of the Hercynian Iberian belt. PreHercynian ages in zircons from the Sotosalbos complex $(-464 \mathrm{Ma})$ are well preserved and reveal that an age diversity of the Lower Paleozoic magmatism in the area exists, as previous data on westernmost orthogneisses yield significant older ages. Zircon ages in the pelite-derived granites from the Toledo complex also show an important Neoproterozoic age component which points to a metasedimentary protolith deposited maximally $560 \mathrm{Ma}$ ago. Younger zircon populations in both complexes at $-330 \mathrm{Ma}$ in the Sotosalbos region and $-317 \mathrm{Ma}$ in the Toledo complex indicate an important diachronism between the anatectic processes in both areas but also that these processes are mainly unrelated to the generation of the later Hercynian granite batholith of Central Spain, which could be of deeper crustal derivation. In
\end{abstract}

addition, as migmatization occurred late in the metamorphic cycle, after peak conditions were attained, the age of anatexis is younger than the age of the main Hercynian metamorphic event, which still is not well constrained.

Keywords SHRIMP U-Pb zircon dating - Migmatite complexes - Anatectic granites - Hercynian Iberian Belt - Gondwana zircon provenance

\section{Introduction}

A typical continental collision orogenic cycle is usually composed of a stage of convergence and crustal thickening followed by a period of crustal thinning. The study of migmatite complexes provides evidence to decipher the history of late metamorphic and magmatic processes during orogeny, and precise dating of migmatization is essential to model the waning stages of orogenesis. In this way, topics like the relation of the migmatites to the temperature peak or their late origin in exhumed-uplifted sectors and their age-relationships with the late, discordant plutonic bodies are important questions that need geochronological data to be addressed. In addition, the refractory character of zircon allows us to study the age and nature of their protoliths. In this work, we present the $\mathrm{U}-\mathrm{Pb}$ age results from five samples collected in two well known anatectic complexes in Central Spain (Fig. 1): the anatectic complex of Sotosalbos (ACS) in the Spanish central system (SCS) and the anatectic complex of Toledo (ACT) (Barbero 1995; Barbero et al. 1995; Martín Romera et al. 1999; Villaseca et al. 2001). 
Fig. 1 Simplified geological sketch of the Central Iberian Zone (Iberian Massif, inset) in Central Spain. The anatectic areas described in the text are boxed

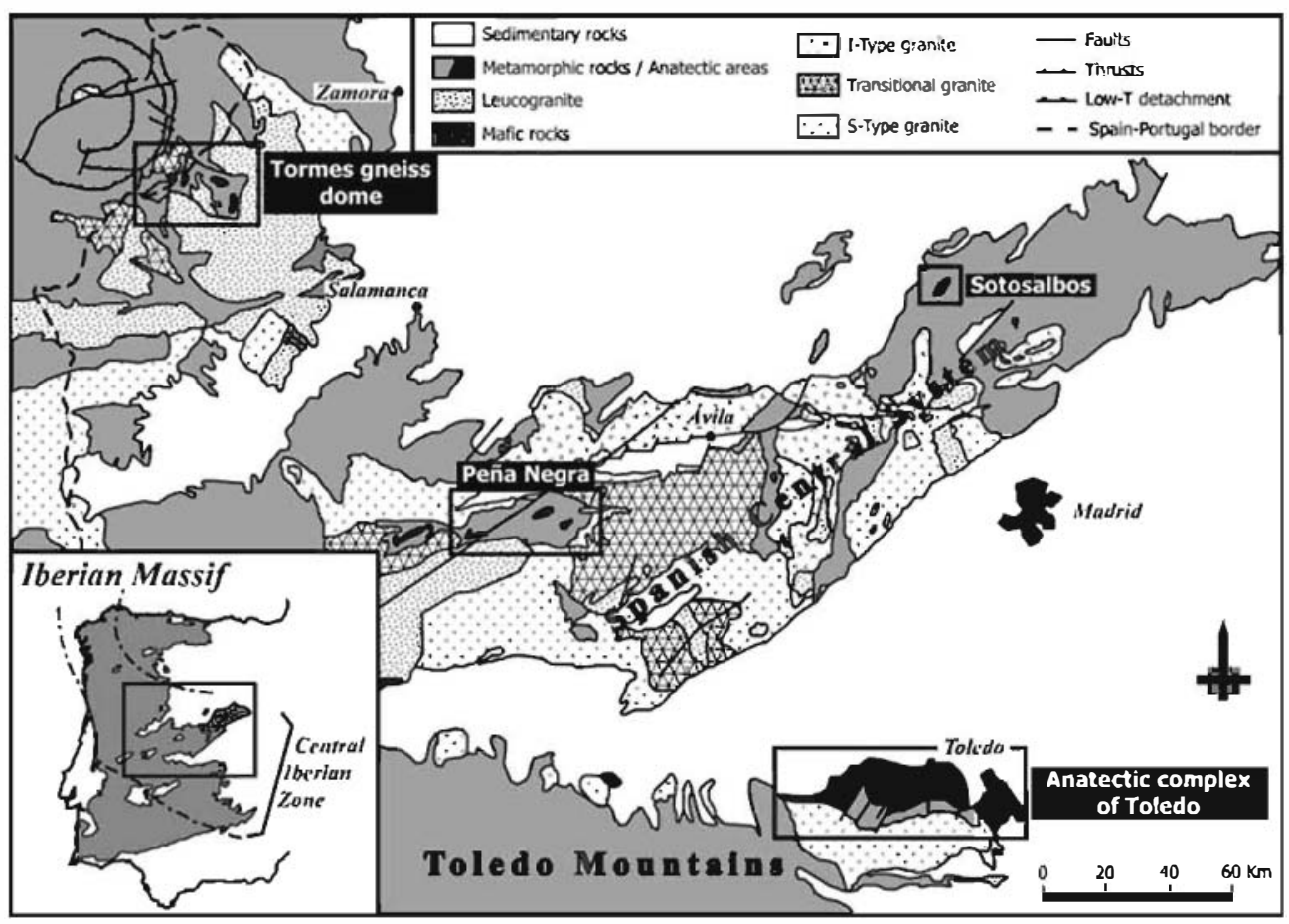

\section{Geological setting and petrographic features of migmatites}

The ACS and ACT complexes crop out in the Central Iberian Zone of the Iberian Massif (Julivert et al. 1972), one of the best preserved sections of the European Hercynian Belt. It is generally accepted that the Central Iberian Zone represents a piece of the external margin of northern Gondwana, involved in the Paleozoic collision with Laurentia after the closure of the Rheic Ocean (see Gibbons and Moreno 2002, and references therein), and it is mainly composed of plutonic and variably metamorphosed rocks, including several migmatite complexes (Fig. 1). In these migmatite areas, peak metamorphic conditions were attained during or immediately after the first Hercynian tectonothermal stage $\left(\mathrm{M}_{1}\right)$, reaching eclogite or granulite facies depending on the structural level (Villaseca et al. 1999), followed by an exhumation stage with pressure differences of around $9-10 \mathrm{~kb}$ from peak pressure conditions of $-14 \mathrm{~kb}$ and re-equilibration pressures of $4-5 \mathrm{~kb}$ (Escuder Viruete et al. 1998; Barbero and Villaseca 2000). Available petrological data indicate that the SCS and nearby areas have recorded a clockwise $P-T$-time $(t)$ evolution and that migmatization is related, to a certain extent, to the low$P$ loop, when temperature was decreasing (Villaseca et al. 2002; Villaseca and Ubanell 2005).

In the ACS, located in the eastern part of the SCS (Fig. 1), the migmatites and the related anatectic granites have cordierite and biotite as mafic minerals, and migmatite metamorphic conditions are estimated around $725 \pm 50^{\circ} \mathrm{C}$ and $4-5 \mathrm{~kb}$ (Martín Romera et al. 1999). The nearby Peña Negra anatectic complex in the western SCS (Fig. 1), shows similar metamorphic characteristics (Bea et al. 1994; Pereira and Rodríguez Alonso 2000). In contrast, the ACT migmatites, located north to the Toledo Mountains (Fig. 1), are characterized by garnet and cordierite as mafic minerals and their calculated metamorphic conditions are $800 \pm 25^{\circ} \mathrm{C}$ and $4-6 \mathrm{~kb}$ (Barbero 1995).

In the ACS, the petrographic and geochemical features of the cordierite-bearing granitoids indicate that they represent restite-rich granites related to migmatized orthogneisses. These anatectic granitoids locally contain cordierite-rich nodules and cockades, corroded augen $\mathrm{K}$-feldspar megacrysts, and orthogneissic xenoliths, suggestive of their derivation from those metaigneous protoliths. Moreover, trace and major element geochemistry combined with $\mathrm{Sr}-\mathrm{Nd}$ isotopes show a good agreement with this orthogneissic derivation (Martín Romera et al. 1999). Two samples from this heterogeneous Sotosalbos cordierite granite were selected (100560 and 100943). They are mediumgrained equigranular rocks consisting of quartz, plagioclase, K-feldspar, biotite, cordierite and accessory tourmaline. Cordierite contains minor inclusions of biotite and sillimanite. Feldspar also contains needles of sillimanite. Some scarce biotite-rich enclaves resemble biotite-rich folia of the augen-gneisses. 
Migmatites of the ACT are mostly derived from pelitic metasediments. Related anatectic leucogranites (Cervatos-type) and restite-rich granitoids (Layostype) appear in the ACT (Barbero et al. 1995). The Layos granite constitutes a suite of rocks ranging from quartz-rich tonalite to melamonzogranite and is characterized by a high modal proportion of cordierite (up to $30 \%$ ). This restite-rich granite is more peraluminous in the more mafic types, a remarkable characteristic of some S-type granites in which more mafic rocks (Qtzrich tonalites) are closer to the composition of their source rocks (Chappell and White 1992; Barbero and Villaseca 1992). The Cervatos leucogranite crops out as vein-like or dyke-like concordant sheets or elongated massifs and, in most cases, is spatially related to the Layos granite. This leucogranite has a modal eutectic composition and displays centimetre-scale layering consisting of garnet-, cordierite- and less frequent biotite-bearing varieties. Two samples of the restiterich Layos granite (M-3 and LY-1) and the Cervatos leucogranite ( $\mathrm{CV}-1)$ have been selected for zircon analysis in this work.

\section{Previous geochronology}

Reliable geochronological information available on the Hercynian migmatization in the Central Iberian Zone is scarce, and the knowledge of its relationship with either the pressure peak or the granite intrusions which built the huge SCS Batholith is limited. Montero et al. (2004) studied a migmatite area outcropping in the western part of the SCS, the Peña Negra Complex (Fig. 1), and they presented a discussion on the implications of the geochronology of migmatite complexes in the Hercynian evolution of the sector. In this work, the authors stated that anatexis occurred for a long period, from 352 to $297 \mathrm{Ma}$, with a maximum at 335-305 Ma, suggesting a coeval emplacement of massif-type granites in mid-crustal levels. Nevertheless, a U-Pb SHRIMP zircon geochronology study in orthogneisses from this Peña Negra Complex suggests an age of $315 \mathrm{Ma}$ for the climax of the Hercynian metamorphism in the western SCS (Zeck et al. 2004). At the starting point of this study, the geochronological data in the Toledo area was limited to a short communication on the anatectic granites from the southern ACT (Barbero and Rogers 1999), giving an age of $310 \mathrm{Ma}$ (U-Pb ID-TIMS in monazites) for the anatectic event. However, recently Bea et al. (2006) have published a SIMS U-Pb zircon study on the temporal relationships between the mafic magmatism and the migmatization in the Toledo area in which they obtained a mean migmatization age of 332 Ma.

In addition, some studies have been devoted to the geochronology of the Hercynian $\mathbf{M}_{2}$ metamorphism in the SCS. U-Pb dating in monazites indicates that the main $\mathrm{D}_{2}$ extensional event (related to the temperature peak) in the eastern part of the SCS took place between 337 and $326 \mathrm{Ma}$ (Escuder Viruete et al. 1998), in accordance with the only $\mathrm{U}-\mathrm{Pb}$ geochronological study on zircons from the western SCS (332 Ma, after Galibert 1984).

Other relevant ages are mainly related to the preHercynian evolution of the Central Iberian Zone. Vialette et al. (1987) presented whole-rock Rb-Sr isochrons from three granitic orthogneisses in the Guadarrama area at around $475-490 \mathrm{Ma}$, which was interpreted as the intrusion ages of the respective granite magmas. Wildberg et al. (1989) dated six orthoand para-gneisses east from Sotosalbos (U-Pb IDTIMS in zircon), yielding Paleoproterozoic upper intercepts, which were interpreted as inherited ages and $-550 \mathrm{Ma}$ lower intercepts, considered as magmatic ages. In addition, they obtained two younger ages related to the Hercynian evolution, -380 and 280300 Ma. Lancelot et al. (1985) dated orthogneisses from the northwestern sector of the Central Iberian Zone, obtaining discordant ages with an upper intercept at $465 \mathrm{Ma}$ (U-Pb ID-TIMS in zircon), and interpreted as a magmatic age. Valverde-Vaquero and Dunning (2000) obtained similar ages (-460-490 Ma, $\mathrm{U}-\mathrm{Pb}$ ID-TIMS in zircon) in orthogneisses located in the Guadarrama area, east of Sotosalbos. More recently, Zeck et al. (2004) dated zircons from another orthogneissic unit southwest of the Peña Negra Complex using SHRIMP, and their results exhibited evidence of the complex history recorded in these rocks in which inherited zircons show different populations between 1,000 and $570 \mathrm{Ma}$ that were incorporated to a magma at $546 \mathrm{Ma}$ and subsequently metamorphosed at -315 Ma.

\section{Zircon description}

Zircons from sample 100560 (a cordierite-bearing granite from ACS) are usually slightly worn out prisms (aspect ratios between 1:2 and 1:3) with distinguishable rims even under a transmitted light microscope. Some longer (1:4-1:7), well-formed prisms can also be found which show no apparent core-rim features under the microscope. Cathodoluminescence images (CL) reveal xenocrystic, inherited cores with variable CL response (Fig. 2). These cores can be surrounded by a light 

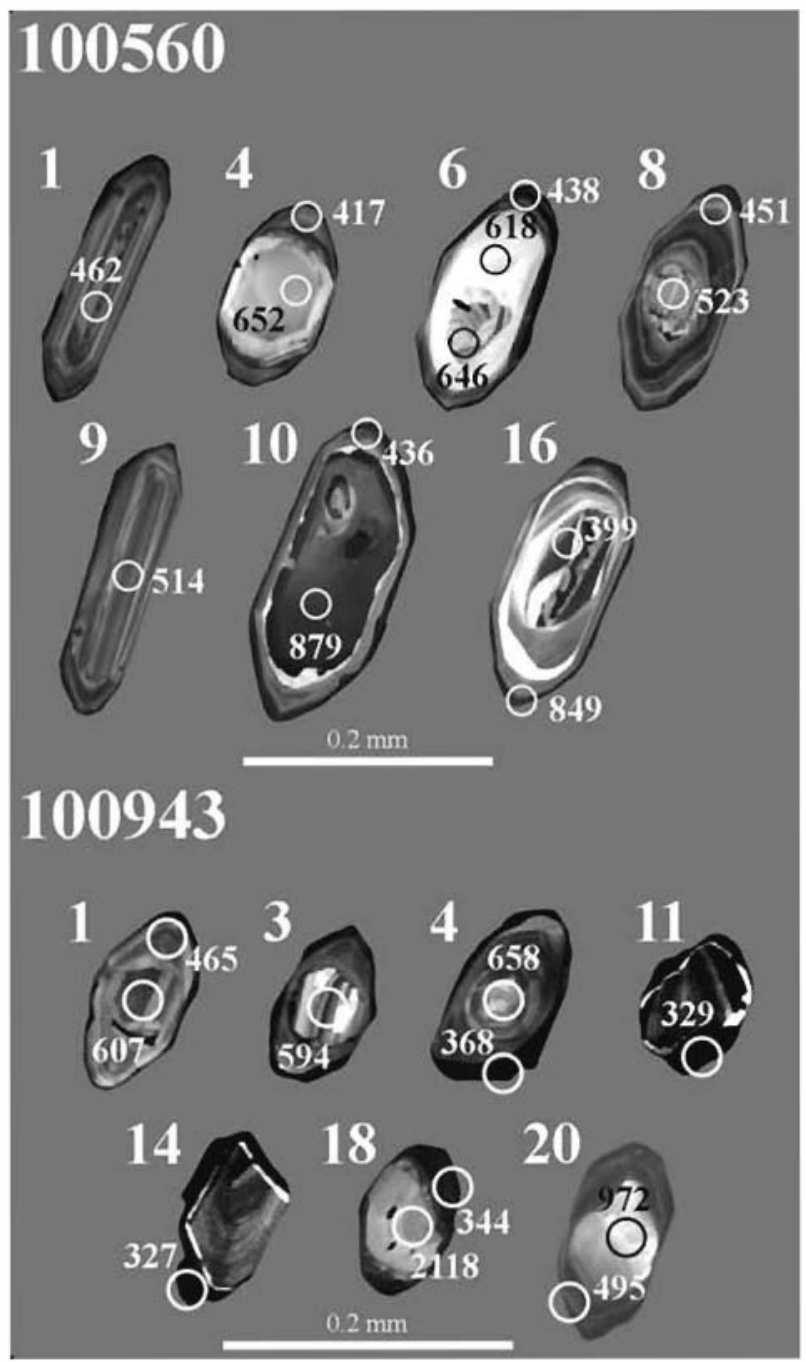

Fig. 2 Cathodoluminescence images of the analyzed zircons from Sotosalbos (samples 100560 and 100943), with the location of the SHRIMP spots

mantle or by a variably thick overgrowth with oscillatory zoning (Fig. 2). The longest prisms exhibit magmatic oscillatory zoning but no cores. Finally, irregular, dark rims $(-15 \mu \mathrm{m}$ thick $)$ can be found in some grains, irrespective of the type of zircon.

Sample 100943 corresponds to the same lithology as the previous sample, and zircons display the same corerim features although they are usually smaller and stubbier. Under CL (Fig. 2), a varied population of xenocrysts can be observed; mantles and oscillatory overgrowths are scarce, but irregular dark rims are common ( $-15 \mu \mathrm{m}$ thick).

Zircons from sample $\mathrm{CV}-1$, an anatectic leucogranite from the ACT, are highly variable, showing differences in size and shape from stubby grains to rounded prisms (1:3-1:5). Core-rim associations are evident, and sometimes a marked oscillatory zoning can be observed even under a transmitted light microscope. CL enhances these core-rim features, showing cores with different luminescence responses always truncated by $-20 \mu \mathrm{m}$ thick dark rims (Fig. 3). In some cases, dark CL areas do not form rims but occupy irregular domains, giving rise to an embayed morphology in the former zircons.

In samples LY-1 and M-3, which are restite-rich granitoids from the ACT, zircons are quite similar. As in $\mathrm{CV}-1$, they are variable in size and shape although small, stubby grains with distinguishable cores and rims under the microscope are dominant. CL images (Fig. 3) reveal that most of the zircons have oscillatoryzoned cores, truncated by dark CL zircon, mainly in the tips. In other cases, there is no overgrowth or it thinly surrounds the whole zircon and has oscillatory zoning as well.

\section{Analytical techniques}

Zircons were isolated following standard separation techniques, followed by hand picking for final purity, and mounted on a double stick tape on glass slides in $1 \times 6 \mathrm{~mm}$ parallel rows together with some chips of zircon standard R33 (Black et al. 2004). After setting them in epoxy resin, the zircons were ground down to expose their central portions and imaged with transmitted and reflected light on a petrographic microscope as well as with cathodoluminescence on a JEOL 5800LV electron microscope (housed at USGS-Denver) to identify internal structures, inclusions, fractures and physical defects. Due to the textural complexity of the zircons, the use of CL images was central to aim at the right area.

Zircon U-Th- $\mathrm{Pb}$ analyses were conducted on the sensitive high resolution ion microprobe-reverse geometry (SHRIMP-RG) operated by the SUMAC facility (USGS-Stanford University). Secondary ions were generated from the target spot with an $\mathrm{O}^{2-}$ primary ion beam varying from 4-6 n A which typically produced a spot with a diameter of $\sim 20$ microns and a depth of 1-2 microns for an analysis time of approximately $10 \mathrm{~min}$. When analyzing rims slightly thinner than the ion beam diameter, the spot was preferably located at the very edge of the zircon, touching the epoxy resin, to avoid core-rim mixed ages. Twelve peaks were measured sequentially in a single collector. Measurements were made at mass resolution of 6,000 8,000 ( $10 \%$ peak height) which eliminated all interfering atomic species. The reverse geometry of the USGS-Stanford SHRIMP provided very clean backgrounds, and combined with the high mass resolution, 
Fig. 3 Cathodoluminescence images of the analyzed zircons from Toledo (samples CV-1, LY-1 and M-3) with the location of the SHRIMP spots
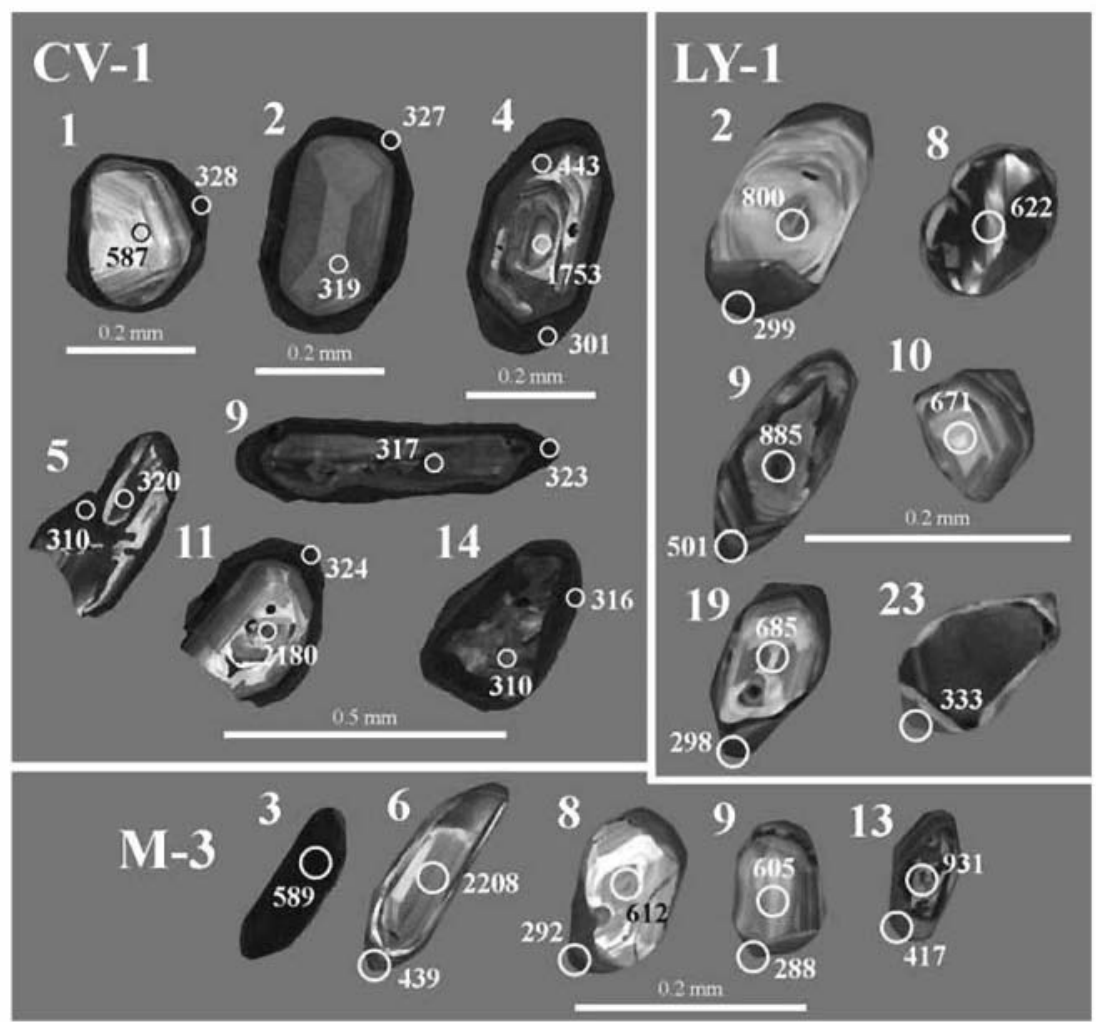

the acid washing of the mount and rastering the primary beam for $90-120$ s over the area to be analyzed before data was collected, assured that any counts found at mass ${ }^{204} \mathrm{~Pb}$ were actually from the zircon.

The accuracy using ion microprobe techniques is achieved at the expense of the precision of the results, as a very small volume of material is sampled. Nevertheless, the precision can be statistically improved by pooling a set of equivalent data together. For this reason, the significance of single results, such as those obtained in detrital populations, can be difficult to evaluate as the occurrence of lead loss can remain unrecognized.

In addition, zircons younger than 1,000 Ma yield poor ${ }^{207} \mathrm{~Pb} /{ }^{206} \mathrm{~Pb}$ ages, thus reducing the efficacy of the $\mathrm{U}-\mathrm{Pb}$ dating method. In order to minimize this drawback, the counting time for ${ }^{206} \mathrm{~Pb}$ was increased to improve counting statistics and precision of the ${ }^{206} \mathrm{~Pb} /{ }^{238} \mathrm{U}$ age.

Concentration data were normalized against zircon standard CZ3 (550 ppm U, Pidgeon et al. 1995), and isotope ratios were calibrated against R33 (419 Ma, Black et al. 2004) which were analyzed repeatedly throughout the duration of the analytical session. Data reduction followed the methods described by Williams (1997), Ireland and Williams (2003), and Squid 1.08 and Isoplot 3.0 software (Ludwig 2002, 2003) were used.

\section{Results}

One hundred-sixteen zircon grains were analyzed in the five samples selected. In almost half of them two or three spots were performed, resulting in a total of 168 analyses. Despite all the measures taken in selecting the adequate spots to prevent common lead contamination, twenty-two of the $<1,000 \mathrm{Ma}$ analyses had common ${ }^{206} \mathrm{~Pb}$ greater than $1 \%$, and they will not be considered in the further discussions. A representative set of analytical data is listed in Tables 1,2 and 3 and plotted in Tera-Wasserburg concordia diagrams (Figs. 4, 5) and probability density diagrams (Figs. 6, 7). The complete set of U-Pb SHRIMP data is provided as supplementary material. Ages younger than $1,000 \mathrm{Ma}$ are 207 -corrected ${ }^{206} \mathrm{~Pb} /{ }^{238} \mathrm{U}$, whereas older ages are 204-corrected ${ }^{207} \mathrm{~Pb} /{ }^{206} \mathrm{~Pb}$.

\section{Anatectic complex of Sotosalbos (ACS)}

On the bases of CL images and $\mathrm{U}-\mathrm{Pb}$ data results, four groups of ages can be distinguished in sample 100560 (Fig. 6). A predominant mean age of $464 \pm 2.6 \mathrm{Ma}$ (MSWD $=0.47$ ) is obtained from five magmatic oscillatory zones (Figs. 4, 6). Older ages are mainly early Paleozoic and Neoproterozoic (500-585 Ma, 620$650 \mathrm{Ma}$ and 780-880 Ma), and a single analysis yields $-1,260 \mathrm{Ma}$. Pre-Hercynian ages younger than $464 \mathrm{Ma}$ 
Table 1 U-Th-Pb SHRIMP representative analytical data for young zircons from the Anatectic Complex of Sotosalbos

\begin{tabular}{|c|c|c|c|c|c|c|c|c|c|c|c|}
\hline \multicolumn{2}{|c|}{$\begin{array}{l}\text { Spot number } \\
\text { and descriplicis }\end{array}$} & $\begin{array}{l}\text { Common } \\
{ }^{206} \mathrm{~Pb}\left({ }^{0 / 6}\right)\end{array}$ & $\mathrm{U}$ (реті) & Th (ppm) & $\mathrm{Th} / \mathbf{U}$ & ${ }^{238} \mathrm{U}^{206} \mathrm{~Pb}^{\mathrm{a}}$ & ${ }^{207} \mathrm{~Pb} /{ }^{206} \mathrm{~Pb}^{\mathrm{a}}$ & ${ }^{238} \mathrm{U} /{ }^{206} \mathrm{~Pb}^{\mathrm{b}}$ & ${ }^{207} \mathrm{~Pb} /{ }^{206} \mathrm{~Pb}^{\mathrm{b}}$ & ${ }^{206} \mathrm{~Pb} /{ }^{238} \mathrm{U}^{\mathrm{c}}$ & ${ }^{206} \mathrm{~Pb} /{ }^{238} \mathrm{U}^{\mathrm{d}}$ age \\
\hline \multicolumn{12}{|c|}{ Anatectic complex of Sotosalbos } \\
\hline \multicolumn{12}{|c|}{ Sample 100560} \\
\hline 1 & $\mathrm{C}$ & $<0.001$ & 314 & 39 & 0.12 & $13.46583 \pm 0.69$ & $0.05553 \pm 1.93$ & $13.49028 \pm 0.69$ & $0.05405 \pm 2.09$ & $0.0743 \pm 0.0005$ & $462 \pm 3$ \\
\hline 4.1 & $\mathrm{C}$ & $<0.001$ & 101 & 165 & 1.63 & $9.41450 \pm 1.20$ & $0.05985 \pm 2.87$ & $9.47005 \pm 1.22$ & $0.05501 \pm 4.29$ & $0.1064 \pm 0.0013$ & $652 \pm 8$ \\
\hline 4.2 & $\mathrm{R}$ & 0.238 & 574 & 26 & 0.04 & $14.92854 \pm 0.41$ & $0.05704 \pm 1.18$ & $14.95125 \pm 0.42$ & $0.05582 \pm 1.77$ & $0.0668 \pm 0.0003$ & $417 \pm 2$ \\
\hline 6.1 & $\mathrm{C}$ & 0.031 & 113 & 37 & 0.33 & $9.48326 \pm 0.98$ & $0.06144 \pm 2.33$ & $9.50469 \pm 0.98$ & $0.05959 \pm 2.81$ & $0.1054 \pm 0.0011$ & $646 \pm 6$ \\
\hline 6.2 & LA & 0.232 & 46 & 12 & 0.27 & $9.91221 \pm 1.53$ & $0.06231 \pm 3.64$ & $9.96183 \pm 1.55$ & $0.05822 \pm 4.88$ & $0.1007 \pm 0.0016$ & $618 \pm 9$ \\
\hline 6.3 & $\mathrm{R}$ & 7.466 & 635 & 12 & 0.02 & $13.16232 \pm 0.36$ & $0.11609 \pm 3.75$ & $14.14043 \pm 0.80$ & $0.06042 \pm 17.36$ & $0.0703 \pm 0.0009$ & $438 \pm 5$ \\
\hline 8.1 & $\mathrm{C}$ & 11.011 & 234 & 39 & 0.17 & $10.52811 \pm 0.76$ & $0.14741 \pm 2.14$ & $11.84773 \pm 1.26$ & $0.05666 \pm 27.19$ & $0.0845 \pm 0.0015$ & $523 \pm 9$ \\
\hline 8.2 & $\mathrm{R}$ & 0.045 & 359 & 38 & 0.11 & $13.78516 \pm 0.56$ & $0.05634 \pm 1.57$ & $13.79583 \pm 0.56$ & $0.05571 \pm 1.76$ & $0.0725 \pm 0.0004$ & $451 \pm 3$ \\
\hline 9 & $\mathrm{R}$ & 0.159 & 302 & 147 & 0.49 & $12.03233 \pm 0.55$ & $0.05887 \pm 1.44$ & $12.05733 \pm 0.55$ & $0.05719 \pm 1.59$ & $0.0830 \pm 0.0005$ & $514 \pm 3$ \\
\hline 10.1 & $\mathrm{C}$ & 0.190 & 588 & 110 & 0.19 & $6.83285 \pm 0.44$ & $0.06992 \pm 0.86$ & $6.83550 \pm 0.44$ & $0.06959 \pm 0.86$ & $0.1461 \pm 0.0007$ & $879 \pm 4$ \\
\hline 10.2 & $\mathrm{R}$ & $<0.001$ & 600 & 5 & 0.01 & $14.30002 \pm 0.49$ & $0.05488 \pm 1.49$ & $14.30973 \pm 0.50$ & $0.05433 \pm 1.72$ & $0.0700 \pm 0.0004$ & $436 \pm 2$ \\
\hline 16.1 & $\mathrm{C}$ & 0.335 & 534 & 90 & 0.17 & $7.07594 \pm 0.63$ & $0.07016 \pm 1.04$ & $7.08270 \pm 0.64$ & $0.06937 \pm 1.25$ & $0.1409 \pm 0.0009$ & $849 \pm 5$ \\
\hline 16.2 & $\mathrm{R}$ & 5.909 & 1945 & 171 & 0.09 & $14.73655 \pm 0.44$ & $0.10241 \pm 1.05$ & $15.67710 \pm 0.63$ & $0.05389 \pm 13.85$ & $0.0638 \pm 0.0006$ & $399 \pm 4$ \\
\hline \multicolumn{12}{|c|}{ Sample 100943} \\
\hline 1.1 & $\mathrm{C}$ & 0.021 & 301 & 282 & 0.94 & $10.13100 \pm 0.58$ & $0.06026 \pm 1.41$ & $10.13917 \pm 0.58$ & $0.05960 \pm 1.47$ & $0.0987 \pm 0.0006$ & $607 \pm 3$ \\
\hline 1.2 & $\mathrm{R}$ & 0.018 & 404 & 38 & 0.09 & $13.36032 \pm 0.46$ & $0.05647 \pm 1.26$ & $13.36838 \pm 0.46$ & $0.05598 \pm 1.33$ & $0.0748 \pm 0.0004$ & $465 \pm 2$ \\
\hline $\mathbf{3}$ & $\mathrm{C}$ & $<0.001$ & 219 & 333 & 1.52 & $10.37029 \pm 0.70$ & $0.05938 \pm 1.74$ & $10.39303 \pm 0.70$ & $0.05759 \pm 2.20$ & $0.0965 \pm 0.0007$ & $594 \pm 4$ \\
\hline 4.1 & $\mathrm{C}$ & $<0.001$ & 171 & 100 & 0.59 & $9.30360 \pm 0.81$ & $0.06132 \pm 1.92$ & $9.31764 \pm 0.81$ & $0.06008 \pm 2.05$ & $0.1075 \pm 0.0009$ & $658 \pm 5$ \\
\hline 4.2 & $\mathrm{R}$ & 0.398 & 2115 & 30 & 0.01 & $16.97248 \pm 0.39$ & $0.05712 \pm 1.01$ & $17.12296 \pm 0.41$ & $0.05000 \pm 3.14$ & $0.0587 \pm 0.0002$ & $368 \pm 1$ \\
\hline 11 & $\mathrm{R}$ & 0.194 & 1717 & 3 & 0.00 & $19.05388 \pm 0.27$ & $0.05457 \pm 0.83$ & $19.11077 \pm 0.28$ & $0.05217 \pm 1.50$ & $0.0524 \pm 0.0001$ & $329 \pm 1$ \\
\hline 14 & $\mathrm{R}$ & 0.605 & 3308 & 30 & 0.01 & $19.10956 \pm 0.19$ & $0.05782 \pm 0.58$ & $19.21508 \pm 0.20$ & $0.05341 \pm 1.54$ & $0.0520 \pm 0.0001$ & $327 \pm 1$ \\
\hline 18.2 & $\mathrm{R}$ & 0.113 & 1191 & 3 & 0.00 & $18.21227 \pm 0.35$ & $0.05427 \pm 1.09$ & $18.28258 \pm 0.36$ & $0.05117 \pm 2.06$ & $0.0548 \pm 0.0002$ & $344 \pm 1$ \\
\hline 20.1 & $\mathrm{C}$ & 0.161 & 93 & 43 & 0.46 & $6.13281 \pm 0.97$ & $0.07287 \pm 1.82$ & $6.15084 \pm 0.98$ & $0.07042 \pm 2.49$ & $0.1628 \pm 0.0017$ & $972 \pm 9$ \\
\hline 20.2 & $\mathrm{R}$ & $<0.001$ & 1206 & 55 & 0.05 & $12.54605 \pm 0.32$ & $0.05682 \pm 0.85$ & $12.55101 \pm 0.32$ & $0.05650 \pm 0.87$ & $0.0797 \pm 0.0003$ & $495 \pm 2$ \\
\hline
\end{tabular}

All errors are $1 \sigma$

$C$ core, $R$ rim, LA light area

a Uncorrected ratios

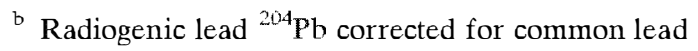

${ }^{0}$ Radiogenic lead ${ }^{207} \mathrm{~Pb}$ corrected for common lead

d ${ }^{207} \mathrm{~Pb}$ corrected for common lead 
Table 2 U-Th-Pb SHRIMP representative analytical data for young zircons from the Anatectic Complex of Toledo

\begin{tabular}{|c|c|c|c|c|c|c|c|c|c|c|c|}
\hline \multicolumn{2}{|c|}{$\begin{array}{l}\text { Spot number } \\
\text { and description }\end{array}$} & $\begin{array}{l}\text { Common } \\
{ }^{206} \mathrm{~Pb}(\%)\end{array}$ & $\mathrm{U}(\mathrm{ppm})$ & Th (ppm) & $\mathrm{Th} / \mathrm{U}$ & ${ }^{238} \mathrm{U} /{ }^{206} \mathrm{~Pb}^{\mathrm{a}}$ & ${ }^{207} \mathrm{~Pb} /{ }^{206} \mathrm{~Pb}^{\mathrm{a}}$ & ${ }^{238} \mathrm{U} /{ }^{206} \mathrm{~Pb}^{\mathrm{b}}$ & ${ }^{207} \mathrm{~Pb} /{ }^{206} \mathrm{~Pb}^{\mathrm{b}}$ & ${ }^{206} \mathrm{~Pb} /{ }^{238} \mathrm{U}^{\mathrm{c}}$ & ${ }^{206} \mathrm{~Pb} /{ }^{238} \mathrm{U}^{\mathrm{d}}$ age \\
\hline \multicolumn{12}{|c|}{$\begin{array}{l}\text { Anatectic complex of Toledo } \\
\text { Sample CV-1 }\end{array}$} \\
\hline 1.1 & $\mathrm{C}$ & 0.239 & 171 & 60 & 0.35 & $10.47344 \pm 0.81$ & $0.06148 \pm 1.99$ & $10.47344 \pm 0.81$ & $0.06148 \pm 1.99$ & $0.0953 \pm 0.0008$ & $587 \pm 5$ \\
\hline 1.2 & $\mathrm{R}$ & $<0.001$ & 1080 & 9 & 0.01 & $19.16364 \pm 0.41$ & $0.05289 \pm 1.30$ & $19.17982 \pm 0.41$ & $0.05221 \pm 1.45$ & $0.0522 \pm 0.0002$ & $328 \pm 1$ \\
\hline 2.1 & $\mathrm{C}$ & 0.215 & 232 & 196 & 0.84 & $19.68903 \pm 0.80$ & $0.05450 \pm 2.51$ & $19.75187 \pm 0.82$ & $0.05193 \pm 3.67$ & $0.0507 \pm 0.0004$ & $319 \pm 3$ \\
\hline 2.2 & $\mathrm{R}$ & 0.123 & 1178 & 9 & 0.01 & $19.19252 \pm 0.35$ & $0.05395 \pm 1.08$ & $19.24001 \pm 0.35$ & $0.05196 \pm 1.57$ & $0.0520 \pm 0.0002$ & $327 \pm 1$ \\
\hline 4.2 & $\mathrm{R}$ & 0.026 & 1303 & 12 & 0.01 & $20.88194 \pm 0.30$ & $0.05257 \pm 1.10$ & $20.88194 \pm 0.30$ & $0.05257 \pm 1.10$ & $0.0479 \pm 0.0002$ & $301 \pm 1$ \\
\hline 4.3 & $\mathrm{R}$ & 0.143 & 457 & 4 & 0.01 & $14.05159 \pm 0.57$ & $0.05691 \pm 1.58$ & $14.03737 \pm 0.57$ & $0.05773 \pm 1.57$ & $0.0711 \pm 0.0004$ & $443 \pm 3$ \\
\hline 5.1 & $\mathrm{C}$ & $<0.001$ & 582 & 713 & 1.22 & $19.67172 \pm 0.52$ & $0.05257 \pm 1.65$ & $19.70370 \pm 0.52$ & $0.05126 \pm 1.77$ & $0.0508 \pm 0.0003$ & $320 \pm 2$ \\
\hline 5.2 & $\mathrm{R}$ & $<0.001$ & 1347 & 10 & 0.01 & $20.29687 \pm 0.30$ & $0.05208 \pm 0.96$ & $20.30026 \pm 0.30$ & $0.05195 \pm 0.98$ & $0.0493 \pm 0.0002$ & $310 \pm 1$ \\
\hline 9.1 & $\mathrm{C}$ & $<0.001$ & 967 & 846 & 0.87 & $19.86282 \pm 0.40$ & $0.05263 \pm 1.29$ & $19.90751 \pm 0.41$ & $0.05082 \pm 1.89$ & $0.0504 \pm 0.0002$ & $317 \pm 1$ \\
\hline 9.2 & $\mathrm{R}$ & 1.082 & 3297 & 18 & 0.01 & $19.26316 \pm 0.21$ & $0.06157 \pm 0.66$ & $19.49025 \pm 0.22$ & $0.05219 \pm 2.70$ & $0.0514 \pm 0.0001$ & $323 \pm 1$ \\
\hline 11.2 & $\mathrm{R}$ & 0.028 & 1276 & 8 & 0.01 & $19.42028 \pm 0.31$ & $0.05311 \pm 0.98$ & $19.43041 \pm 0.31$ & $0.05269 \pm 1.01$ & $0.0515 \pm 0.0002$ & $324 \pm 1$ \\
\hline 14.1 & $\mathrm{C}$ & 0.426 & 570 & 112 & 0.20 & $20.20799 \pm 0.50$ & $0.05599 \pm 1.56$ & $20.27538 \pm 0.54$ & $0.05332 \pm 3.46$ & $0.0493 \pm 0.0003$ & $310 \pm 2$ \\
\hline 14.2 & $\mathrm{R}$ & $<0.001$ & 1407 & 9 & 0.01 & $19.92315 \pm 0.33$ & $0.05225 \pm 1.07$ & $19.93554 \pm 0.33$ & $0.05175 \pm 1.13$ & $0.0502 \pm 0.0002$ & $316 \pm 1$ \\
\hline \multicolumn{12}{|c|}{ Sample LY-1 } \\
\hline 2.1 & $\mathrm{C}$ & $<0.001$ & 132 & 79 & 0.60 & $7.58833 \pm 0.86$ & $0.06406 \pm 1.87$ & $7.59408 \pm 0.86$ & $0.06343 \pm 1.97$ & $0.1321 \pm 0.0012$ & $800 \pm 7$ \\
\hline 2.2 & $\mathrm{R}$ & 0.100 & 507 & 2 & 0.00 & $21.03318 \pm 0.50$ & $0.05312 \pm 1.61$ & $21.05987 \pm 0.50$ & $0.05210 \pm 1.84$ & $0.0475 \pm 0.0002$ & $299 \pm 2$ \\
\hline 8 & $\mathrm{C}$ & $<0.001$ & 223 & 354 & 1.59 & $9.88682 \pm 0.67$ & $0.05938 \pm 1.59$ & $9.89983 \pm 0.67$ & $0.05830 \pm 1.67$ & $0.1013 \pm 0.0007$ & $622 \pm 4$ \\
\hline 9.1 & $\mathrm{C}$ & 0.527 & 411 & 580 & 1.41 & $6.76334 \pm 0.60$ & $0.07290 \pm 0.98$ & $6.78335 \pm 0.61$ & $0.07046 \pm 1.64$ & $0.1471 \pm 0.0009$ & $885 \pm 5$ \\
\hline 9.2 & $\mathrm{R}$ & 0.303 & 405 & 6 & 0.02 & $12.33088 \pm 0.49$ & $0.05971 \pm 1.30$ & $12.34797 \pm 0.49$ & $0.05859 \pm 1.67$ & $0.0809 \pm 0.0004$ & $501 \pm 2$ \\
\hline 10 & $\mathrm{C}$ & 0.084 & 79 & 48 & 0.61 & $9.10993 \pm 1.10$ & $0.06259 \pm 2.57$ & $9.12235 \pm 1.11$ & $0.06148 \pm 2.80$ & $0.1097 \pm 0.0013$ & $671 \pm 7$ \\
\hline 19.1 & $\mathrm{C}$ & 0.062 & 94 & 68 & 0.73 & $8.91629 \pm 1.04$ & $0.06282 \pm 2.39$ & $8.92683 \pm 1.04$ & $0.06185 \pm 2.58$ & $0.1121 \pm 0.0012$ & $685 \pm 7$ \\
\hline 19.2 & $\mathrm{R}$ & 0.010 & 527 & 2 & 0.00 & $21.11044 \pm 0.55$ & $0.05237 \pm 1.81$ & $21.16582 \pm 0.55$ & $0.05027 \pm 2.19$ & $0.0474 \pm 0.0003$ & $298 \pm 2$ \\
\hline 23 & $\mathrm{R}$ & 0.014 & 385 & 2 & 0.01 & $18.85417 \pm 0.67$ & $0.05322 \pm 2.31$ & $18.93643 \pm 0.69$ & $0.04971 \pm 3.76$ & $0.0530 \pm 0.0004$ & $333 \pm 2$ \\
\hline \multicolumn{12}{|c|}{ Sample M-3 } \\
\hline 3 & $\mathrm{C}$ & 0.016 & 1340 & 741 & 0.55 & $10.44415 \pm 0.28$ & $0.05974 \pm 0.60$ & $10.44519 \pm 0.28$ & $0.05966 \pm 0.61$ & $0.0957 \pm 0.0003$ & $589 \pm 2$ \\
\hline 6.2 & $\mathrm{R}$ & 0.537 & 482 & 10 & 0.02 & $14.12987 \pm 0.54$ & $0.06000 \pm 1.66$ & $14.23613 \pm 0.61$ & $0.05395 \pm 4.96$ & $0.0704 \pm 0.0004$ & $439 \pm 2$ \\
\hline 8.1 & $\mathrm{C}$ & $<0.001$ & 75 & 79 & 1.06 & $10.05589 \pm 1.18$ & $0.05964 \pm 4.02$ & $10.13329 \pm 1.24$ & $0.05334 \pm 7.45$ & $0.0995 \pm 0.0012$ & $612 \pm 7$ \\
\hline 8.2 & $\mathrm{R}$ & 0.383 & 547 & 2 & 0.00 & $21.49544 \pm 0.73$ & $0.05523 \pm 2.41$ & $21.52472 \pm 0.74$ & $0.05414 \pm 2.87$ & $0.0463 \pm 0.0004$ & $292 \pm 2$ \\
\hline 9.1 & $\mathrm{C}$ & 0.018 & 142 & 27 & 0.19 & $10.15824 \pm 0.88$ & $0.06019 \pm 2.18$ & $10.18709 \pm 0.88$ & $0.05787 \pm 2.33$ & $0.0984 \pm 0.0009$ & $605 \pm 5$ \\
\hline 9.2 & $\mathrm{R}$ & 0.475 & 352 & 9 & 0.02 & $21.77494 \pm 1.32$ & $0.05587 \pm 4.42$ & $22.21670 \pm 1.57$ & $0.03967 \pm 19.18$ & $0.0457 \pm 0.0006$ & $288 \pm 4$ \\
\hline 13.2 & $\mathrm{R}$ & 0.353 & 418 & 1 & 0.00 & $14.89556 \pm 0.66$ & $0.05798 \pm 1.92$ & $14.94304 \pm 0.66$ & $0.05541 \pm 2.39$ & $0.0669 \pm 0.0005$ & $417 \pm 3$ \\
\hline 13.1 & $\mathrm{C}$ & $<0.001$ & 866 & 205 & 0.24 & $6.44436 \pm 0.32$ & $0.06912 \pm 0.64$ & $6.44732 \pm 0.32$ & $0.06874 \pm 0.68$ & $0.1554 \pm 0.0005$ & $931 \pm 3$ \\
\hline
\end{tabular}

All errors are $1 \sigma$

$C$ core, $R$ rim

a Uncorrected ratios

b Radiogenic lead ${ }^{204} \mathrm{~Pb}$ corrected for common lead

${ }^{c}$ Radiogenic lead ${ }^{207} \mathrm{~Pb}$ corrected for common lead

d ${ }^{207} \mathrm{~Pb}$ corrected for common lead 
Table 3 U-Th-Pb SHRIMP analytical data for old zircons from the Anatectic Complexes of Sotosalbos and Toledo

\begin{tabular}{|c|c|c|c|c|c|c|c|c|c|c|}
\hline $\begin{array}{l}\text { Spot number } \\
\text { and description }\end{array}$ & $\begin{array}{l}\text { Common } \\
{ }^{206} \mathrm{~Pb}(\stackrel{0}{1})\end{array}$ & $\mathrm{U}(\mathrm{ppm})$ & Th (ppm) & $\mathrm{Th} / \mathrm{U}$ & ${ }^{207} \mathrm{~Pb}^{*}{ }^{206} \mathrm{~Pb}^{*}, \mathrm{a}$ & ${ }^{207} \mathrm{~Pb}^{*} / 235 \mathrm{U}^{\mathrm{b}}$ & ${ }^{206} \mathrm{~Pb}^{*}{ }^{238} \mathrm{U}^{\mathrm{b}}$ & $\begin{array}{l}\text { Error } \\
\text { correlation }\end{array}$ & $\begin{array}{l}{ }^{207} \mathrm{~Pb} /{ }^{206} \mathrm{~Pb}^{\mathrm{b}} \\
\text { age }\end{array}$ & $\begin{array}{l}\text { Discordant } \\
(\%)\end{array}$ \\
\hline \multirow{2}{*}{\multicolumn{11}{|c|}{$\begin{array}{l}\text { Anatectic complex of Sotosalbos } \\
\text { Sample } 10056\end{array}$}} \\
\hline & & & & & & & & & & \\
\hline 13.1 & 0.17 & 467 & 88 & 0.19 & $0.0824 \pm 0.8$ & $2.37 \pm 0.9$ & $0.2085 \pm 0.5$ & 0.522 & $1256 \pm 15$ & 3 \\
\hline \multicolumn{11}{|l|}{ Sample 100943} \\
\hline 18.1 & $<0.01$ & 80 & 56 & 0.70 & $0.1315 \pm 1.7$ & $7.41 \pm 2.0$ & $0.4088 \pm 1.0$ & 0.512 & $2118 \pm 29$ & -4 \\
\hline \multicolumn{11}{|c|}{ Anatectic complex of Toledo } \\
\hline \multicolumn{11}{|c|}{ Sample CV -1} \\
\hline 4.1 & 2.08 & 144 & 78 & 0.54 & $0.1072 \pm 1.1$ & $3.74 \pm 1.4$ & $0.2527 \pm 1.0$ & 0.680 & $1753 \pm 19$ & 21 \\
\hline 11.1 & 0.95 & 348 & 159 & 0.46 & $0.1362 \pm 0.5$ & $7.18 \pm 0.8$ & $0.3824 \pm 0.6$ & 0.767 & $2180 \pm 9$ & 4 \\
\hline 15 & 2.37 & 52 & 29 & 0.57 & $0.1809 \pm 4.4$ & $11.84 \pm 4.6$ & $0.4748 \pm 1.3$ & 0.283 & $2661 \pm 73$ & 6 \\
\hline \multicolumn{11}{|l|}{ Sangle LY-1 } \\
\hline 26.1 & 1.26 & 47 & 6 & 0.13 & $0.1869 \pm 1.0$ & $13.08 \pm 1.6$ & $0.5076 \pm 1.3$ & 0.772 & $2715 \pm 17$ & 3 \\
\hline \multicolumn{11}{|l|}{ Sannfle M-3 } \\
\hline 6.1 & $<0.01$ & 108 & 69 & 0.64 & $0.1384 \pm 0.8$ & $7.99 \pm 1.2$ & $0.4185 \pm 0.9$ & 0.716 & $2208 \pm 15$ & -2 \\
\hline 10.1 & $<0.01$ & 29 & 55 & 1.95 & $0.2258 \pm 2.1$ & $19.11 \pm 2.6$ & $0.6138 \pm 1.6$ & 0.599 & $3023 \pm 34$ & -2 \\
\hline
\end{tabular}

All errors are $1 \sigma$

C core

* Radiogenic lead

a Uncorrected ratio

${ }^{\mathrm{b}}$ Radiogenic lead ${ }^{204} \mathrm{~Pb}$ corrected for common lead 

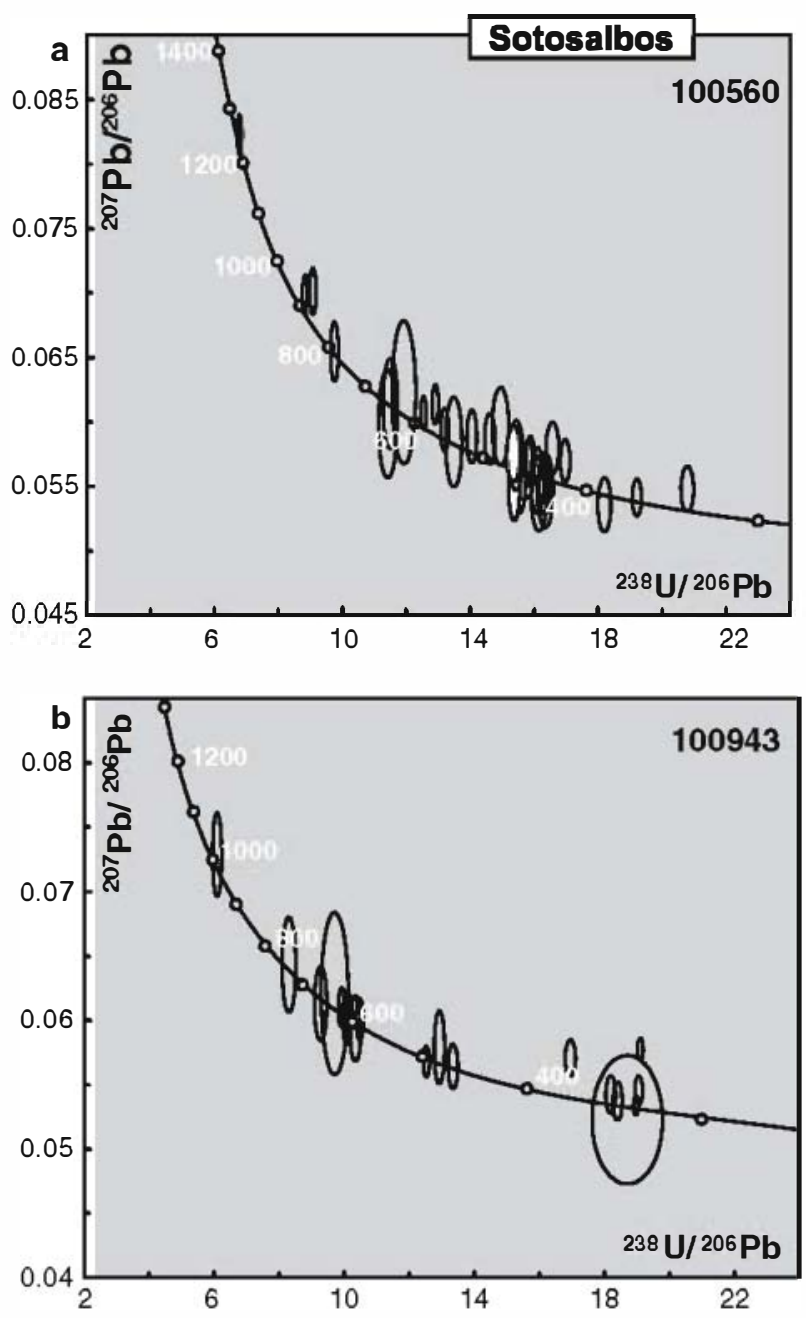

Fig. 4 Tera-Wasserburg plot showing distribution of SHRIMP $\mathrm{U}-\mathrm{Pb}$ zircon ages in samples from Sotosalbos, a sample 100560 , white ellipses represent the data considered to obtain the mean age of the Ordovician magmatism, b sample 100943, where a Paleoproterozoic analysis is not shown. Error ellipses are $\pm 2 \sigma$

are obtained from narrow rims in some grains with low $\mathrm{Th} / \mathrm{U}$ ratios, and they could represent a zircon formation event at $-440 \mathrm{Ma}$. Finally, Hercynian ages are very scarce, and they are obtained in dark irregular rims, ranging from -335 to $-390 \mathrm{Ma}$. This dispersion will be discussed further on.

Results in sample 100943 are slightly different (Figs. 4,6). In this case, only three groups of ages can be distinguished. The predominant group is represented by seven analyses and corresponds to dark rims yielding an approximate mean age of $330 \mathrm{Ma}$ although a minor dispersion of ages, from 327 to $368 \mathrm{Ma}$ is observed. The next group is composed of three analyses in magmatic zones (two rims and one core) that clump together, giving an approximate age of $480 \mathrm{Ma}$. Finally, seven xenocrystic cores
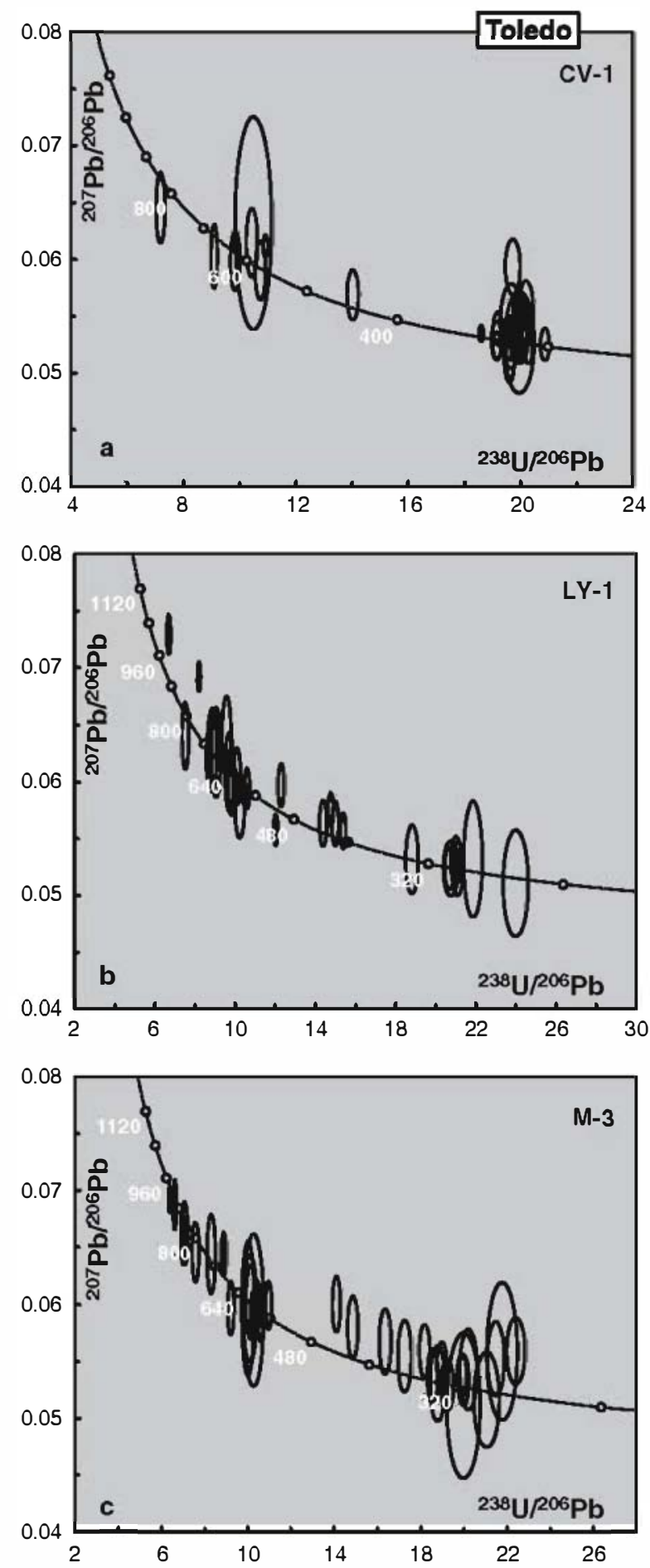

Fig. 5 Tera-Wasserburg plot showing distribution of SHRIMP zircon analyses in samples from Toledo, a CV-1 (anatectic leucogranite), b LY-1 (restite-rich granite), and c M-3 (granite). Older inherited analyses are not shown. Error ellipses are $\pm 2 \sigma$

yield Neoproterozoic ages (600-730 and -970 Ma) and there is also an Early Proterozoic data $(-2,120 \mathrm{Ma})$. 
Fig. 6 Relative probability plots for a Sotosalbos and b Toledo. The main ages discussed in the text are highlighted
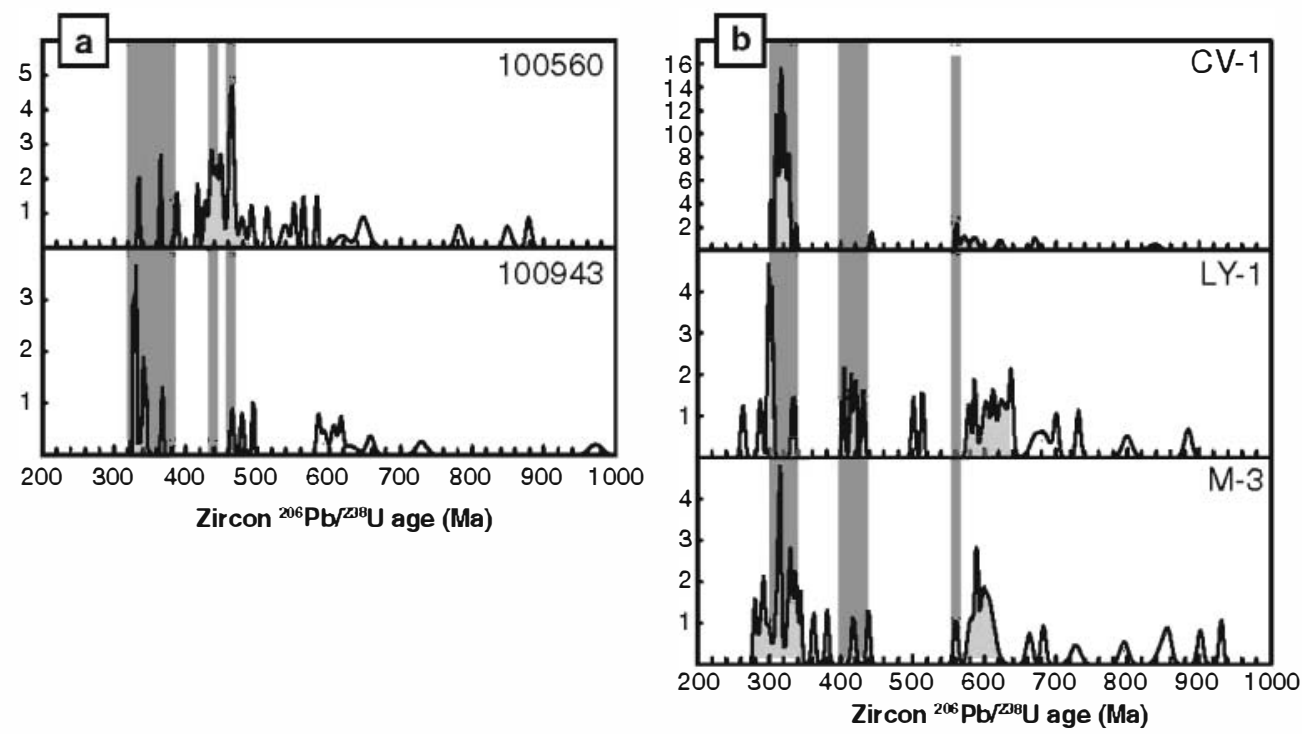

Anatectic complex of Toledo (ACT)

Results in leucogranite CV-1 are dominated by Hercynian ages ( $-300-340 \mathrm{Ma})$; whereas, just one-third of the analysis yield inherited ages (Figs. 5, 6). This inheritance is mainly of Neoproterozoic age $(-560$ $670 \mathrm{Ma})$, with some scattered results at $-440,-840$, $-2,180$ and $-2,660 \mathrm{Ma}$. Hercynian ages are obtained not only in rims but also in apparently xenocrystic cores, suggesting that different Hercynian episodes of zircon growth existed (Fig. 3, zircon grains 2, 5, 9 and 14). Those texturally discordant cores could be the result of a zircon recrystallization during the magmatic (anatectic) event that could have disturbed the isotopic content of older zircons; however, in some grains no evidence of such recrystallization was found (Fig. 3, zircon grain 2). Therefore, we consider that they represent distinct zircon growth events. In order to pinpoint their age, we plot separately rim and core data in a probability density diagram, where several groups of ages can be observed (Fig. 7a) in a wide range (310$330 \mathrm{Ma})$.

In samples LY-1 and M-3, the inherited xenocrystic cores are better preserved and resulted in a wider spectrum of ages (Fig. 6). The distribution of inheritance is similar in both samples, and it resembles the faint distribution obtained in sample $\mathrm{CV}-1$, suggesting that the metasedimentary protolith is equivalent in all the ACT samples (Fig. 6). The predominant group of inherited ages ranges from -560 to $-650 \mathrm{Ma}$ and some scarce older Neoproterozoic ages can be found ( -660 $730 \mathrm{Ma}$ and $-800-930 \mathrm{Ma}$ ). In addition, Late Proterozoic and Archean ages are obtained in three cores $(-2,200,-2,700$ and $-3,000 \mathrm{Ma})$. Despite the high common lead content in some of the inherited cores, these ages are considered significant as concordance is greater than $90 \%$. Another group of ages is obtained from dark, low $\mathrm{Th} / \mathrm{U}$ rims, and the results cluster around $425 \mathrm{Ma}$. Finally, two ages of $-510 \mathrm{Ma}$ are only found in sample LY-1. The Hercynian ages in these samples are also distributed over a wide time span. In sample LY-1, some scarce dark zircon tips (and a dark prism) yield ages from -260 to $-330 \mathrm{Ma}$, with a cluster of four analysis at $301.2 \pm 4.6 \mathrm{Ma}(\mathrm{MSWD}=3.3$ ). In sample M-3, Hercynian rims are more abundant ranging in age from -280 to $-360 \mathrm{Ma}$, with a peak at $314.2 \pm 1.9 \mathrm{Ma}(\mathrm{MSDW}=0.94)$.

\section{Interpretation and discussion of the results}

Age and nature of pre-migmatitic protoliths

In the ACS, the good preservation of pre-Hercynian zircons in the granites is remarkable even though the original orthogneissic fabric has been mostly obliterated during the Hercynian anatectic event. More than the $85 \mathrm{vol} \%$ of the zircon crystals was inherited from the protolith as restitic minerals, and they resisted events of $700-800^{\circ} \mathrm{C}$ without major recrystallization. Considering the biggest population of youngest magmatic zircons, a concordia age of $464 \pm 2.6 \mathrm{Ma}$ can be obtained in sample 100560; whereas, in sample 100943, three analyses yield an approximate age of $-480 \mathrm{Ma}$. Both ages are in agreement with previously published $\mathrm{U}-\mathrm{Pb}$ and $\mathrm{Rb}-\mathrm{Sr}$ ages in Guadarrama orthogneisses (Vialette et al. 1987; Wildberg et al. 1989; ValverdeVaquero and Dunning 2000). Nevertheless, recently 

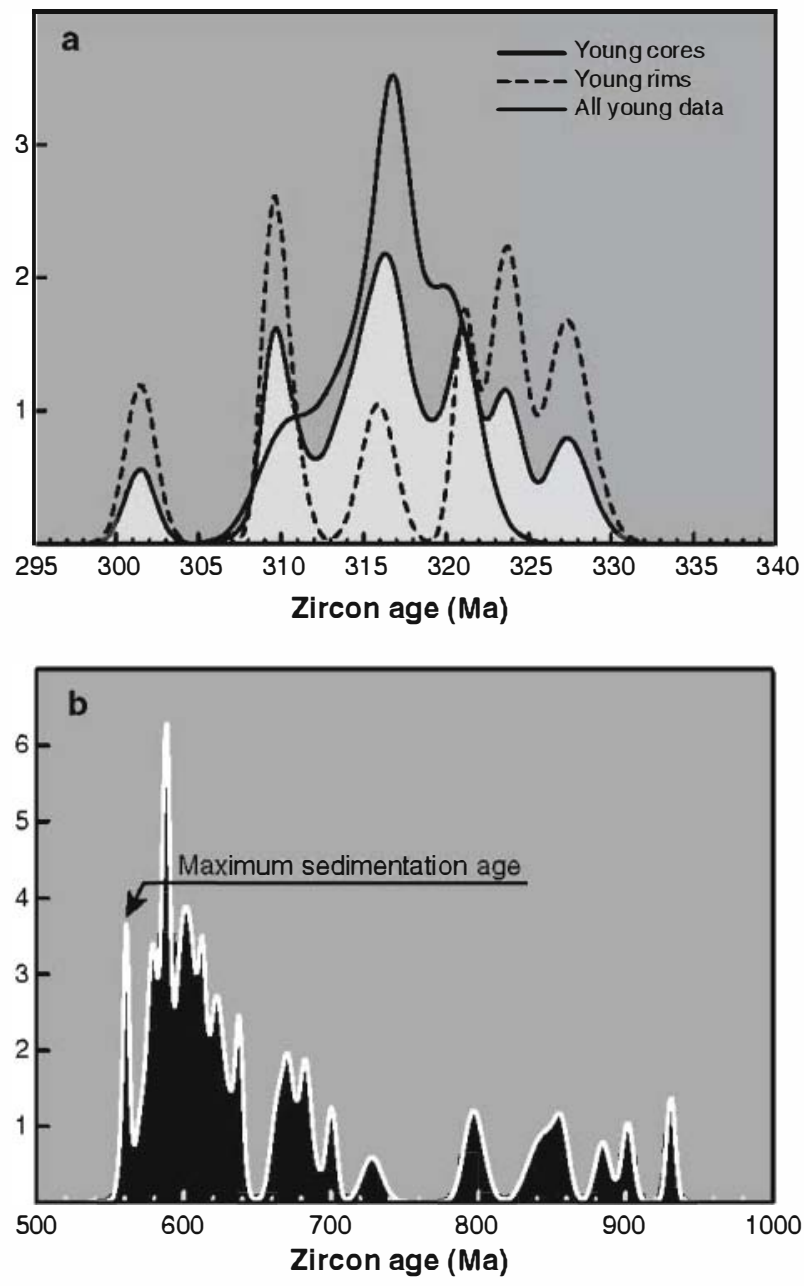

Fig. 7 Relative probability plots showing a possible episodes of zircon growth recognized in sample CV-1 and $\mathbf{b}$ the minimum age of detrital zircons in all the samples from Toledo represents the maximum age of the deposition of the sedimentary protolith

dated augen orthogneissic samples from the western part of the SCS yield ages from 546 to $525 \mathrm{Ma}$ (SHRIMP in zircon, Zeck et al. 2004, and single-crystal evaporation in zircon, Bea et al. 2003) evidencing a marked diachronism of this Lower Paleozoic felsic peraluminous magmatism in the SCS. This diachronism is a common feature in the Hercynian complexes of Central Europe (e.g. Finger et al. 2000, and references therein). Cocherie et al. (2005) propose that the protracted and intense magmatic activity characterizing the basement of the southern European terranes, when compared to the northern Gondwana margin, supports a possible individualization of these terranes before Ordovician times.

The preservation of inherited ages in the pelite-derived Toledo migmatites also suggests that zircon recrystallization during partial melting events is less effective than previously supposed in melt-rich migmatites (e.g. Nemchin et al. 2001; Villaseca et al. 2003; Moecher et al. 2004), and that zircon is mainly incorporated as restitic material, with only minor precipitation of zircon during melting. Additionally, the scatter in the Hercynian ages shown in Fig. 4 suggests that isotopic equilibrium is hardly attained in anatectic melts during the new zircon growth event due to the incomplete dissolution of inherited zircon grains. A similar effect was previously described in the $\mathrm{Sr}-\mathrm{Nd}$ isotope systematics from the same rocks (Barbero et al. 1995). However, due to the thinness of some zircon rims, it is possible that the scattered Hercynian data are mixed ages as a result of hitting older domains.

The ages recorded in zircon grains from ACT granites should be significant in characterizing the sources of the sedimentary protolith and in estimating its depositional age. In this way, when plotting the ages of the detrital grains from the ACT samples (Fig. 7b), we can assume that the minimum age of $-560 \mathrm{Ma}$ represents the maximum depositional age for the sedimentary protolith (Nelson 2001). This age coincides with the estimated stratigraphic age of the Ibor-Navalpino Group (Rodríguez Alonso et al. 2004) to which they supposedly could be correlated.

The presence of a single Mesoproterozoic age is incompatible with the accepted idea of a "Mesoproterozoic gap" typical of Gondwana sediments with West African sources as occurs in other European Hercynian terranes (e.g. Kober et al. 2004), and in contrast to sources which exhibit Mesoproterozoic detrital zircon populations from the Amazonian craton (Friedl et al. 2000). The singularity of this Mesoproterozoic age ( 1,260 Ma obtained from the Sotosalbos granite) could have led us to doubt its geological significance on the basis of the accepted paleogeographic models and to reject this "anomalous" analysis arguing the possible existence of Pb-loss. However, Sánchez Martínez et al. (2006) have found a piece of a $-1,160 \mathrm{Ma}$ ophiolite involved in the Hercynian suture of NW Spain, suggesting that pieces of Mesoproterozoic crust were incorporated to the West African terranes during the assembly of Rodinia, giving a geological significance to our single Mesoproterozoic age.

Finally, a group of analyses in thin dark rims (low in $\mathrm{Th} / \mathrm{U}$ ratios) cluster around $440-425 \mathrm{Ma}$ in samples from both anatectic complexes. Low $\mathrm{Th} / \mathrm{U}$ ratios are commonly interpreted as the consequence of a metamorphic event (Hoskin and Black 2000). However, the lack of geological evidence in the studied area supporting any metamorphic event at that age suggests that they could represent mixed ages between thin rims and cores. 
4.5 kb, Martín Romera et al. 1999) confirm that after

$P-T$ paths in high-grade terranes of the Central Iberian Zone suggest that migmatization occurs in the low- $\mathrm{P}$ part of the $P-T$ evolution after peak $P-T$ conditions have been attained. This is well illustrated in the Tormes gneiss dome (Fig. 1) and in the eastern SCS domain (where ACS crops out), where complete $P-T$ paths have been established (Escuder Viruete et al. 2000; Barbero and Villaseca 2000). In the Tormes gneiss dome, Escuder Viruete et al. (2000) have obtained a $P$ $T$ path with two metamorphic stages: a first compressive phase reaching upper amphibolite facies conditions and a subsequent near-isothermal decompression episode during which a high-T fabric was developed and local partial melting occurred (Fig. 8). In the SCS, the first Hercynian tectonothermal stage $\left(\mathrm{M}_{1}\right)$ could reach eclogite conditions, but was only preserved in some metabasic layers (Barbero and Villaseca 2000). This is followed by an exhumation stage with pressure differences of around 9-10 kb from peak pressure conditions of $-14 \mathrm{~kb}$ until low-pressure re-equilibration at $4-5 \mathrm{~kb}$, when migmatization occurs (Fig. 8). Coronitic mafic granulites interlayered within the augen orthogneisses record an intermediate exhumation stage, giving recrystallization conditions of $830^{\circ} \mathrm{C}$ and $7-8 \mathrm{~kb}$, (Villaseca et al. 2002). Finally, $P-T$ conditions obtained for the migmatization in Sotosalbos area $\left(725^{\circ} \mathrm{C}\right.$ and the metamorphic peak, some cooling took place during exhumation. $P-T$ paths intersect biotite-breakdown reactions at low pressure and decreasing temperature although the exact locus of the intersection depends on the whole-rock chemistry (Fig. 8).

In other migmatitic areas (Peña Negra or Toledo), $P-T$ paths are not complete; however, the portion of the path deduced from mineral paragenesis in the ACT (Barbero 1995) indicates that migmatization occurred during the low-P evolution of the rocks after peak conditions were surpassed (Fig. 8).

The Hercynian ages obtained in this study are considered to correspond to the migmatization event. The high dispersion in the data from both anatectic areas can be interpreted in two ways. On one hand, the dispersion could have been isotopically influenced by the partial dissolution of inherited zircons. This interpretation is supported by the abundance of old zircons and the disequilibrium observed in whole-rock geochemistry and isotopic systems (Barbero et al. 1995). On the other hand, the recognition of different growth stages (Figs. 4, 7a) can be explained as the result of a protracted migmatitic event. A similar interpretation has been proposed to explain the ages obtained in the Peña Negra complex (Bea et al. 2003) and other migmatitic complexes (e.g. Finger and Clemens 1995; Keay et al. 2001; Tropper et al. 2006). Nevertheless, it is
Fig. $8 P-T-t$ paths from different migmatitic areas in the Central Iberian Zone. Tormes Gneiss Dome path after Escuder Viruete et al. (2000); Guadarrama path after Escuder Viruete et al (1998) and Villaseca and Ubanell (2005); Sotosalbos path after Barbero and Villaseca (2000); and Toledo path after Barbero (1995).

Petrogenetic grid after Spear et al. (1999)

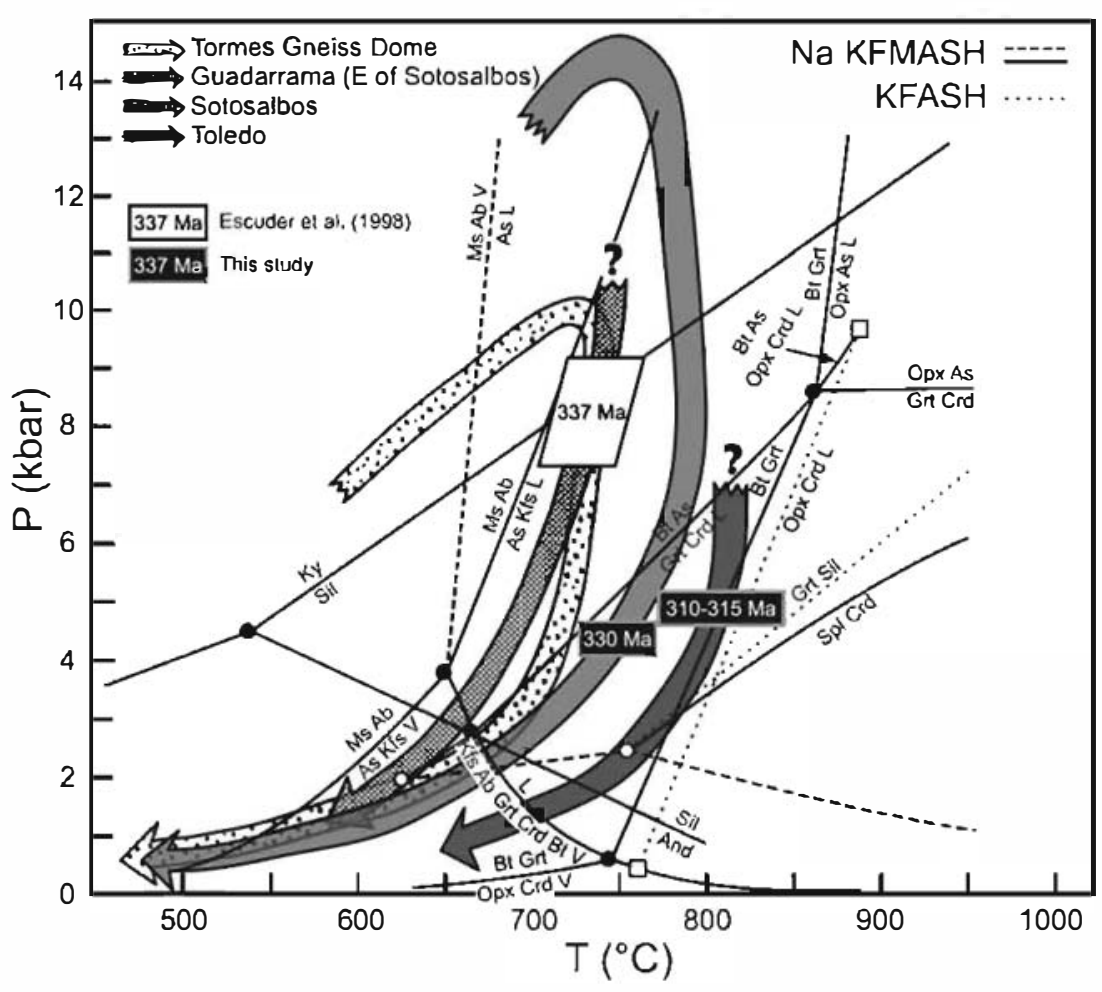


possible that a combination of both processes occurred, evidencing the complex evolution in these anatectic areas. In the ACS, taking into account the scarcity of new zircon growth during the anatectic event and the influence of inherited zircons, we interpret that the dispersion of the Hercynian ages is the result of an incomplete isotopic re-equilibration with inherited zircon domains. Therefore, we consider $-330 \mathrm{Ma}$ as the most probable age for the migmatization in the Sotosalbos area.

In the ACT, the main zircon growth has been dated at $-317 \mathrm{Ma}$ although other episodes of zircon growth could have occurred at -300 and -325 Ma. In sample $\mathrm{CV}-1$, the age dispersion could be the result of different zircon growth episodes during a long migmatitic event; however, in sample M-3, the trends defined in the concordia plot suggest that younger ages than $-315 \mathrm{Ma}$ could have been affected by lead loss; whereas, older ages could be the result of incomplete isotopic equilibration.

In any case, diachronism between both anatectic areas can be observed, and it reflects the complexity of the migmatization event in the waning stages of the Hercynian orogenesis. Recently, Bea et al. (2006) present new results in two migmatite samples from the ACT. They propose an age for the migmatization surprisingly older (332 Ma). However, the age interval they obtained is similar to our data ( 350 to $320 \mathrm{Ma}$ ), suggesting that their older age could be biased due to a limited dataset (14 versus our 50 analyses) and poses the question of which would be the minimum amount of analyses necessary to properly characterize complex geologic processes like long-lived migmatization events similar to the one described in Montero et al. (2004). It is also noteworthy that our youngest migmatization ages overlap the age of the mafic magmatism from the Toledo area obtained by Bea et al. (2006). Nevertheless, new additional data and future geochronological work are needed to clarify this discussion.

The age of the migmatization is slightly younger than the estimated age for the extensional event in the SCS, which supposedly occurred between 337 and $332 \mathrm{Ma}$, based on textural relationships and $\mathrm{U}-\mathrm{Pb}$ dating of accessory phases (Galibert 1984; Escuder Viruete et al. 1998). This is in agreement with the petrologic evidence suggesting that anatexis took place late in the Hercynian cycle during the exhumation of metamorphic core complexes (Barbero 1995).

This late origin with respect to the thermal peak for the studied migmatite terranes in the Central Iberian Zone is also comparable with other European Hercynian terranes, where ages for intermediate-P and high$\mathrm{T}$ granulites vary from 345 to $330 \mathrm{Ma}$ (Kröner et al.
1998; Chen et al. 2003; Gordon et al. 2005). In the southeast of the French Massif Central, migmatization has been dated between 329 and 323 Ma (Be Mezeme et al. 2006), closer in ages to those exposed in this work. Nevertheless, two successive high-T events have been described in the Velay anatectic dome (French Massif Central), the youngest (at $-305 \mathrm{Ma}$ ) being responsible for most of the cordierite-bearing granites which characterize this dome (Ledru et al. 2001).

\section{Relationships with plutonic granitoids}

Most of the geochronological data on Hercynian plutonic magmatism from the Central Iberian Zone indicate that the major volume of granites was emplaced during the $\mathrm{D}_{3}$ ductile deformation phase at 320 310 Ma (Dias et al. 1998; Fernández Suárez et al. 2000; Valle-Aguado et al. 2005). Migmatite complexes from the eastern SCS (e.g. Sotosalbos) are not spatially related to allochtonous syn-intrusive granites. Peraluminous granites intrude later in these migmatite areas which are consequently cooled, and typical aureolecontact metamorphism develops related to the epizonal emplacement of those undeformed granite plutons, mostly in the age range of 310-285 Ma (Villaseca et al. 1995; Casquet et al. 2004). For this reason, the SCS granite batholith appears mostly discordant with the regional metamorphic structures, and thus is considered as post-metamorphic granites (e.g. Villaseca et al. 1995). This situation is similar to that described in the southern part of the French Massif Central, where late-Hercynian plutonic granites are mostly dated from 318 to $311 \mathrm{Ma}$, clearly intrusive in nearby high- $\mathrm{T} \mathrm{mi-}$ gmatite areas (Be Mezeme et al. 2006).

However, other migmatite complexes from Central Spain show coeval intrusion of plutonic bodies from deeper sources during anatexis. In the ACT, some calk-alkaline basic and acid bodies (Barbero et al. 1990) and S-type granites (Barbero 1992) intrude previously or during regional migmatization. In the nearby Peña Negra complex the presence of peraluminous granodiorites with mafic enclaves is also described which, nevertheless, has been interpreted as subautochthonous plutonic bodies (Pereira and Rodríguez Alonso 2000; Montero et al. 2004).

The presence of more mafic granitoids (Ca-Fe richer monzogranites or granodiorites) than the common eutectic-like composition of melt-rich migmatites (leucosomes and leucogranites) is suggestive of the lower crustal derivation of most of the pluton-size SCS granitoids, either syn- $\mathrm{D}_{3}$ or post- $\mathrm{D}_{3}$ types, in good agreement with geochemical and isotopic balance with residual granulites from SCS xenolith suites (Villaseca 
et al. 1999; Villaseca et al. 2001). Moreover, a recent $\mathrm{U}-\mathrm{Pb}$ geochronological study on those lower crustal xenoliths (Fernández-Suárez et al. 2006) shows that nearly $90 \mathrm{vol} \%$ of the granulitic zircon re-crystallized during the time span of 277-312 Ma, in accordance with ages of exposed granites. Large-scale melting in lower-crustal scenarios seems to be younger than the limited partial melting which occurred in migmatite terranes at mid-crustal levels. Thus, several mid- to lower-crustal layers were partially melted at different times during the late Hercynian period.

\section{Concluding remarks}

The analysis of small areas of composite zoned zircons provided by ion microprobe techniques is the key to elucidating the history of intricate rocks. The coupled CL and geochronological study of zircons in anatectic granites and related rocks is essential to the knowledge on the origin and evolution of the migmatitic complexes. In this study, the two samples analyzed from Sotosalbos give us information about the West African provenance of the former sediments, which were incorporated into a granitic melt at $-460 \mathrm{Ma}$ and subsequently migmatized during the late stages of the Hercynian orogeny. Regarding the three samples analyzed from the Toledo area, the geochronological information obtained also includes the West African provenance of the sedimentary protolith, and its maximum depositional age $(-560 \mathrm{Ma})$ can be deduced from the detrital zircon population. The complexity of the Hercynian metamorphism is evident in the dispersion of the age data and can be the result either of an isotopic disequilibrium and subsequent disturbance of the system, or the existence of a protracted migmatitic event with at least three episodes of zircon precipitation. A marked diachronism in anatexis between both migmatite complexes is also evident and lends a late Hercynian age to this crustal re-melting event. Moreover, although several mid- to lower-crustal layers were partially melted at different times during the late Hercynian period, larger-scale melting in lower-crustal scenarios seems to be the most appropriated source for the post-orogenic SCS granite batholith.

Acknowledgments The authors are grateful to the people at SUMAC facility for their assistance during the SHRIMP-RG analytical sessions, especially J. Wooden and F. Mazdab. We also thank J. Gómez-Barreiro for his help during the dating sessions. The preliminary version of this paper was improved thanks to the careful reviews by I. Braun, Ph. Rossi and F. Finger. Ch. Kaas is kindly acknowledged for her help in the English version. This work has been supported by the Spanish Commission for Science and Technology, project CGL2004-02515, and was done while P.C. was holding a Fulbright postdoctoral fellowship at University of Colorado, financed by Spanish Ministerio de. Educación y Ciencia. This work is also included in the objectives of the Consolider-Ingenio 2010 Programme under the project CSD2006-0041 "TOPO-IBERIA". P. C. thanks I. Brownfield, at the USGS-Denver Microbeam Laboratory, for her help during the CL imaging of the zircons. J. Paces, J. Aleinikoff and W. Premo provided the necessary equipment to prepare and image the SHRIMP mounts.

\section{References}

Barbero L (1992) Plutonismo sin-orogénico en un área granulítica Hercínica: el Complejo Anatéctico de Toledo. PhD Thesis, Universidad Complutense de Madrid, pp 1-455

Barbero L (1995) Granulite-facies metamorphism in the anatectic complex of Toledo, Spain: late Hercynian tectonic evolution by crustal extension. J Geol Soc London $152: 365-382$

Barbero L, Villaseca C (1992) The layos granite, hercynian complex of Toledo (Spain): an example of parautochthonous restite-rich granite in a granulitic area. Trans $\mathbf{R}$ Soc Edinburgh. Earth Sci 83:127-138

Barbero L, Rogers G (1999) Implications of U-Pb monazite ages from syn-orogenic granites of the anatectic complex of Toledo (Spain) in the evolution of the central part of the Hercynian Iberian Belt. Doc BRGM 290:203

Barbero L, Villaseca C (2000) Eclogite facies relics in metabasites from the Sierra de Guadarrama (Spanish Central System) $P-T$ estimations and implications for the Hercynian evolution. Min Mag 64:815-836

Barbero L, Villaseca C, Andonaegui P (1990) On the origin of the gabbro-tonalite-monzogranite association from Toledo area (Hercynian Iberian Belt). Schweizerische Mineralogische und Petrografische Mitteilungen 70:207-219

Barbero L, Villaseca C, Rogers G, Brown PE (1995) Geochemical and isotopic disequilibrium in crustal melting: an insight from anatectic +granitoids from Toledo, Spain. J Geophys Res 100:15745-15765

Be Mezeme E, Cocherie A, Faure M, Legendre O, Rossi PH (2006) Electron microprobe monazite geochronology of magmatic events: examples from Variscan migmatites and granitoids, Massif Central, France. Lithos 87:276-288

Bea F, Pereira MD, Stroh A (1994) Mineral/leucosome traceelement partitioning in a peraluminous migmatite (a laser ablation-ICP-MS study). Chem Geol 117:291-312

Bea F, Montero P, Zinger T (2003) The nature, origin, and thermal influence of the granite source layer of Central Iberia. J Geol 111:579-595

Bea F, Montero P, Gonzalez-Lodeiro F, Talavera C, Molina JF, Scarrow JH, Whitehouse MJ, Zinger T (2006) Zircon thermometry and $\mathrm{U}-\mathrm{Pb}$ ion-microprobe dating of the gabbros and associated migmatites of the Variscan Toledo anatectic complex, Central Iberia. J Geol Soc London 163:847-855

Black LP, Kamo SL, Allen CM, Davis DW, Aleinikoff JN, Valley JW, Mundil R, Campbell IH, Korsch RJ, Williams IS, Foudoulis C (2004) Improved ${ }^{206} \mathrm{~Pb} /{ }^{238} \mathrm{U}$ microprobe geochronology by the monitoring of a trace-element-related matrix effect, SHRIMP, ID-TIMS, ELA-ICP-MS and oxygen isotope documentation for a series of zircon standards. Chem Geol 205:115-140 
Casquet C, Montero P, Galindo C, Bea F, Lozano R (2004) Geocronología ${ }^{207} \mathrm{~Pb} /{ }^{206} \mathrm{~Pb}$ en cristal único de circón y $\mathrm{Rb}-\mathrm{Sr}$ del plutón de La Cabrera (Sierra del Guadarrama). Geogaceta 35:71-74

Chappell BW, White AJR (1992) I- and S-type granites in the Lachlan Fold Belt. Trans R Soc Edinb Earth Sci 83:1-26

Chen F, Todt W, Hann HP (2003) Zircon and garnet geochronology of eclogites from the Moldanubian zone of the Black Forest, Germany. J Geol 111:207-222

Cocherie A, Baudin Th, Autran A, Guerrot C, Fanning CM, Laumonier B (2005) U-Pb zircon (ID-TIMS and SHRIMP) evidence for the early Ordovician intrusion of mic (agranditcs in the late Proterozoic Canaveilles Group of the Pyrenees and the Montagne Noire (France). Bull Soc Géol Fr 176:269-282

Dias G, Leterrier J, Mendes A, Simoes PP, Bertrand JM (1998) $\mathrm{U}-\mathrm{Pb}$ zircon and monazite geochronology of post-collisional Hercynian granitoids from the Central Iberian Zone (Northern Portugal). Lithos 45:349-369

Escuder Viruete J, Hernáiz PP, Valverde-Vaquero P, Rodríguez $R$, Dunning $G$ (1998) Variscan syncollisional extension in the Iberian Massif: structural, metamosphic and geochronoIngical evidence from the Somosierra sector of the Sierra de Guadamama (Central Iberian Zone, Spairi). I'cctonophysics 290:87-109

Escuder Viruete J, Indares A, Arenas R (2000) $P-T$ paths derived from parnet growth zoning in an extensional setting: an example from the Tormes Gneiss Dome (Iherian Massif, Spain). J Petrol 41:1489-1515

Fesnández. Suárez J, Dunning GR, Jenner GA, Gutiérrez Alonso $G$ (2000) Variscan collisional magmatism and deformation in NW Iberia: constraints from $\mathrm{U}-\mathrm{Pb}$ geochronology of granitoids. J Geol Soc London 157:565-576

Fernández Suárez J, Arenas R, Jeffries T, Whitehouse MJ, Villaseca C (2006) A U-Pb study of zircons from a lower crustal granulite xenolith of the Spanish Central System: a record of Iberian lithospheric evolution from the Neopro terozoic to the Triassic. J Geol 114:471-483

Finger F, Clemens JD (1995) Mignatization and "secondary" granitic magmas: effects of emplacement and crỵstallization of "primary" granitoids in southern Bohemia, Austria. Contuih Mineral Petrol 120:311-326

Füjuger F, Hanžl P, Pin C, von Quadt A, Steyrer HP (2000) The Brunovistulian: Avalonian Precambrian sequence at the eastern end of the Central European Variscides? In: Franke W, Haak V, Oncken O, Tanner D (eds) Orogenic processes: quantification and modeling in the Variscan Belt. Geological Society, London, Special Publication 179, pp. 103-112

Friedl G, Finger F, McNaughton NJ, Fletcher IR (2000) Deducing the ancestry of terranes: SHRIMP evidence for South America-derived Gondwana fragments in central Europe. Geology 28:1035-1038

Galibert $\Gamma$ (1984) Géchimie et géochronologie du complexe granitique de l'antiforme de Morille (Salamanca, Espapne). Rapport de Stage de DEA Lab Géochimie Isotopique, Iniv Montpellier, pp 1.-53

Gibbons W, Moreno T (2002) The gcology of Spain. Geological Society, London. $649 \mathrm{pp}$

Gordon SM, Schneider DA, Manecki M, Holm DK (2005) Exhumation and metamorphism of an ultrahigh-grade terrane: geochronometric investigations of the Sudetes Mountains (Bohemia), Poland and Czech Republic. J Geol Soc London 162:841-855

Hoskin PWO, Black LP (2000) Metamorphic zircon formation by solid-state recrystallization of protolith igneous zircon. J Metamorphic Geol 18:423-439
Ireland TR, Williams IS (2003) Considerations in zircon geochronology by SIMS. In: Hanchar JM, Hoskin PWO (eds) Zircon. Reviews in mineralogy and geochemistry 53:215-241

Julivert M, Fonboté JM, Ribeiro A, Conde LN (1972) Mapa Tectónico de la Península Ibérica y Baleares E 1:1000000. Instituto Geológico y Minero de España, Madrid

Keay S, Lister G, Buick I (2001) The timing of partial melting, Barrovian metamorphism and gratice intrusion in the Naxos metamontic core complex. Cyclades, Aegean Sea, Greece. I'ectomophysics 342:275-312

Kober B, Kalt A, Hant M, Pidece on RT (2004) SHRIMP dating of zircons from high-grate metasediments of the Schwarzwuald/SW-Germany and implications for the evolution of the Moldanubian basement. Contrib Mineral Petrol 147:330-345

Kröner A, Jaeckel P, Reischmann T, Kroner U (1998) Further evidence for an early Carboniferous ( $340 \mathrm{Ma})$ age of highgrade metamorphism in the Saxonian granulite complex. Geol Runsd 86:751-766

Lancelot JR, Allegret A, Iglesias Ponce de León M (1985) Outline of Upper Precambrian and Lower Jalcostric cwolution of the Iberian Peninsula according to $\mathrm{U}-\mathrm{Pb}$ daritig of zircons. Earth Planet Sci Lett 74:325-337

Ledru P, Courrioux G, Dallain C, Lardeaux JM, Montel JM, Vanderhaeghe O, Vitel G (2001) The Velay dome (French Massif Central): melt generation and granite emplacement during orogenic evolution. Tectonophysics $342: 207 \ldots 2.37$

I udwip KR (2092) SQIIJD 1.02, a user's manual. Berkeley Geochromology Center Special Publication 2, pp 1-17

Ludwig KR (2003) isoploritix, version 3, A Geochronological Toolkit for Microsoft Excel. Berkeley Geochronology Center Special Publication 4, pp 1-71

Martín Romera C, Villaseca C, Barbero L (1999) Materiales anatécticos en el área de Sotosalbos (Segovia, Sierra de Guadarrama). Caracterización petrológica, geoquímica e isotopica (Sr, Nd). Actas II Congreso Ibérico de Geoqui mica Lisboa 329-332

Moecher DP, Samson SD, Miller CF (2004) Precise time and conditions of peak Taconian granulite facies metamornhism in the southern Appalachian orogen, USA, with implica. tions for zircon behaviour during crustal melting events. J Geol 112:289-304

Montero P, Bea F, Zingct TF, Scarrow JH, Molina JF, Whitehouse M (2004) 55 million years of continuous anatexis in Central Iberia: single-zircon dating of the Peña Negra complex. J Geol Soc Lond 161:255-263

Nelson DR (2001) An assessment of the determination of depositional ages for precambrian clastic sedimentary rocks by U-Pb dating of detrital zircons. Sed Geol 141-142:37-60

Nemchin AA, Giannini LM, Bodorkos S, Oliver NHS (2001) Ostwald ripening as a possible mechanism for zircon overgrowths formation during anatexis: theoretical constraints, a numerical model, and its application to pelitic mipmatites of the Tickalara Metamorphics, northwestern Australia. Geochim Cosmochim Acta 65:2771-2788

Pereira MD, Rodrigucz. Alonso MD (2000) Duality of cordierite granites related to melt-restite scorgation in the Peña Negra anatectic complex, Central Spain. Can Mineral 38:1329-1346

Pidgeon RT, Furfaro D, Kennedy AK, Nemchin AA, van Bronswik W (1995) Calibration of zircon standards for the Curtin SHRIMP II. US Geol Survey Circular 1107:251

Rodríguez Alonso MD, Díez Balda MA, Perejon A, Pieren A, I inán E, I opez. Díaz F, Moreno F, Gámez Vintaned JA, González Lodeiro F, Martínez Poyatos D, Vegas R (2004) 
La secuencia lifocstratigráfica del Neoproterozoico-Cámbrico Inferior del Donirio dcl Compalcjo Esquisto-Grauváquico. In: Vera JA (ed) Gcoloyía de Españà fp 78-81

Sánchez Martínez S, Jeffries T, Arenas R, Firnándč-Suárez J, García-Sánchez R (2006) A pre-Rodinian ophiolite envolved in the Variscan suture of Galicia (Cabo Ortegal Complex, NW Spain). J Geol Soc London 163:737-740

Spear FS, Kohn MJ, Cheney JT (1999) $P-T$ paths from anatectic pelites. Contrib Mineral Petrol 134:17-32

Tropper P, Deibl I, Finger F, Kaindl R (2006) P-T-t evolution of spinel-cordierite-garnet gneisses from the Sauwald Zone (Southern Bohemian Massif, Upper Austria): is there evidence for two independent late-Variscan low-P/high- $\mathrm{T}$ events in the Moldanubian Unit? Int J Earth Sci 95:10191037

Valle-Aguado B, Azevedo MR, Schaltegger U, Martínez Catalán JR, Nolan J (2005) U-Pb zircon and monazite geochronology of Variscan magmatism related to syn-convergence extension in central Northern Portugal. Lithos 82:169-184

Valverde-Vaquero P, Dunning GR (2000) New U-Pb ages for Early Ordovician magmatism in Central Spain. J Geol Soc London 157:15-26

Vialette Y, Casquet C, Fúster JM, Ibarrola E, Navidad M, Peinado M, Villaseca C (1987) Geochronological study of the orthogneisses from the Sierra de Guadarrama (Spanish Central System). Neues Jarbuch für Mineralogie Monatshefte H10:465-479

Villaseca C, Ubanell AG (2005) El macizo metagranítica de La Cebollera (Pico de las Tres Provincias, Somosierra, Sistema Central Español): nuevos datos sobre el metamorfismo Hercínico del sector de Somosierra. Rev Soc Geol España 18:115-131
Villaseca C, Eugercios L, Snelling NJ, Huertas MJ, Castellón T (1995) Nuevos datos geocronológicos (Rb-Sr, K-Ar) de granitoides hercínicos de la Sierra de Guadarrama. Rev Soc Geol España 8:129-140

Villaseca C, Downes H, Pin C, Barbero L (1999) Nature and composition of the lower continental crust in central Spain and the granulite-granite linkage: inferences from granulitic xenoliths. J Petrol 40:1465-1496

Villaseca C, Martín Romera C, Barbero L (2901) Melts and residua geochemistry in a low-to-mid crustal section ( $\mathrm{CHT}-$ tral Spain). Phys Chem Earth 26:273-280

Villaseca C, Martín Romera C, Barbero L (2002) Estimaciones termobarométricas en los metagabros coroníticos de la región de Scyovia (Sicra de Guadarrama). Gcopacta 32:11-14

Villaseca C, Martín Romera C, de la Rosa J, Barbero L (2003) Residence and redistribution of REE, $\mathrm{Y}, \mathrm{Zr}$, Th and $\mathrm{U}$ during granulite-facies metamorphism: behaviour of accessory and major phases in peraluminous granulites of central Spain. Chem Geol 200:293-323

Wildberg HGH, Bischoff L, Baumann A (1989) [i-Ph ages of zircons from meta-igneous and metasedimettatyrocks of the Sierra de Guadarrama: implicarions for the Central Iberian crustal evolution. Contrib Mincral Petrol 103:253-262

Williams IS (1997) U-Th-Pb geochronology by ion microprobe: not jusı ages but histories. Econ Geol 7:1-35

Zeck HP, Wingate MTD, Pooley GD, Ugidos JM (2004) A sequence of Pan-African events recorded in zircons from an orthogneiss from the Jiercymian Belt of western Central Iberia- an ion microprobe U-Pb study. J Petrol 45:16131629 